bioRxiv preprint doi: https://doi.org/10.1101/2022.01.13.476208; this version posted January $13,2022$. The copyright holder for this preprint

(which was not certified by peer review) is the author/funder, who has granted bioRxiv a license to display the preprint in perpetuity. It is made available under aCC-BY 4.0 International license.

A1-paper v17-eLife.docx

\title{
Von Willebrand factor A1 domain affinity for GPIbo and stability are differentially regulated by its O-glycosylated N-linker and C-linker
}

Running title: Biophysical regulation of VWF by O-glycosylated linkers

.

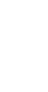

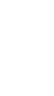

.

(1)

(1)

(2)

(6)

\section{Keywords: von
conformational change}
${ }^{1}$ Children's Hospital Boston and Department of Biological Chemistry and Molecular Pharmacology, Harvard Medical School, Boston, Massachusetts 02115, USA.
${ }^{2}$ Department of Chemistry and Chemical Biology, Northeastern University, Boston, Massachusetts 02115 , USA

${ }^{3}$ Department of Physics, East Carolina University, Greenville, NC 27858

*Correspondence:

Timothy A Springer

Center for Life Science - 03103

3 Blackfan Circle, Boston MA 02115

springer@crystal.harvard.edu

P 617.919 .6935 | F 617.730 .4731

Impact Statement. Both the polypeptide and attached O-glycans N-terminal to the A1 domain in von Willebrand factor lower its affinity for its ligand GPIb $\alpha$ on platelets, its stability, and structural dynamics and decrease population of a high-affinity, intermediate state in unfolding.

\section{Key points:}

- Ligand-binding affinity of A1 and the stability of its native state is regulated by an N-terminal interdomain, O-glycosylated linker

\begin{abstract}
. (241/250)
Hemostasis in the arterial circulation is mediated by binding of the A1 domain of the ultralong protein von Willebrand factor to GPIb $\alpha$ on platelets to form a platelet plug. A1 is activated by tensile force on VWF concatemers imparted by hydrodynamic drag force. The A1 core is protected from force-induced unfolding by a long-range disulfide that links cysteines near its $\mathrm{N}$ and C-termini. The O-glycosylated linkers between A1 and its neighboring domains, which transmit tensile force to A1, are reported to regulate A1 activation for binding to GPIb, but the mechanism is controversial and incompletely defined. Here, we study how these linkers, and their polypeptide and O-glycan moieties, regulate A1 affinity by measuring affinity, kinetics, thermodynamics, hydrogen deuterium exchange (HDX), and unfolding by temperature and urea. The N-linker lowers A1 affinity 40-fold with a stronger contribution from its O-glycan than polypeptide moiety. The N-linker also decreases HDX in specific regions of A1 and increases thermal stability and the energy gap between its native state and an intermediate state, which is observed in urea-induced unfolding. The C-linker also decreases affinity of A1 for GPIb $\alpha$, but in contrast to the N-linker, has no significant effect on HDX or A1 stability. Among different models for A1 activation, our data are consistent with the model that the intermediate state has high affinity for GPIb $\alpha$, which is induced by tensile force physiologically and regulated allosterically by the N-linker.
\end{abstract}


bioRxiv preprint doi: https://doi.org/10.1101/2022.01.13.476208; this version posted January $13,2022$. The copyright holder for this preprint (which was not certified by peer review) is the author/funder, who has granted bioRxiv a license to display the preprint in perpetuity. It is made available under aCC-BY 4.0 International license.

A1-paper v17-eLife.docx

\section{INTRODUCTION}

The ultra-long length of the blood plasma protein

von Willebrand factor (VWF) enables its activation by

hydrodynamic forces at sites of hemorrhage (Springer, 2014)

(Fig. 1A and B). VWF, a long concatemer of monomers

linked head-to-head and tail-to-tail, undergoes a change of

its multimeric superstructure from a compact, random coil

form (Parker \& Lollar, 2021) to a thread-like, extended form

when exposed to elongational flow (Bonazza et al., 2015; Fu

et al., 2017). Hydrodynamic flow activates VWF to bind to

Glycoprotein Ib (GPIb) on platelets, the essential interaction

required for hemostasis and thrombosis in the arteriolar

circulation. Fluorescent imaging of single VWF concatemers

tethered in a flow cell showed that binding of GPIba not

only requires elongation of VWF but also a half-maximal

tensile force of $\sim 20 \mathrm{pN}$ transmitted through the backbone of

VWF concatemers (Fu et al., 2017). Activation could be

well fit to a model of transition from a low-affinity state 1 to

a high affinity state 2 (Figure 1B). Measuring A1-GPIb $\alpha$

binding and unbinding with laser tweezers also revealed two

states, with a force dependent switch between two states

with different on and off-rates (Kim et al., 2015; Kim et al.,

2010). In addition to such flex-bond measurements, A1 and

GPIb $\alpha$ are also reported to form catch-bonds, although these

measurements lack single molecule fiduciary markers or fits

to models from which on and off-rates could be extracted (Ju

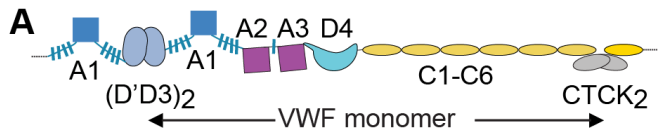

B

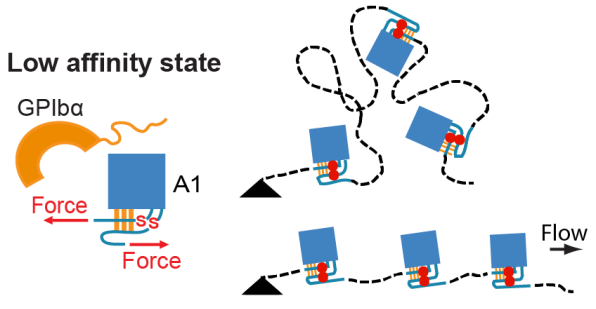

High affinity state

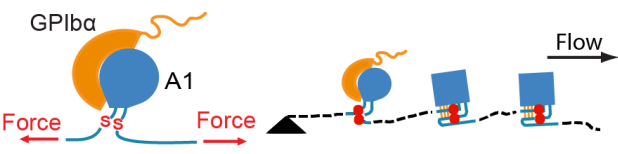

C

A1short

$\mathrm{A} 1+\mathrm{C}$

$\mathrm{A} 1+\mathrm{N}$

$\mathrm{A} 1+\mathrm{N}+\mathrm{C}$

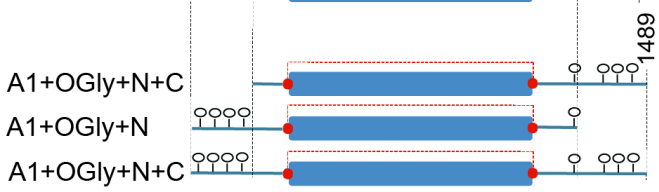

D

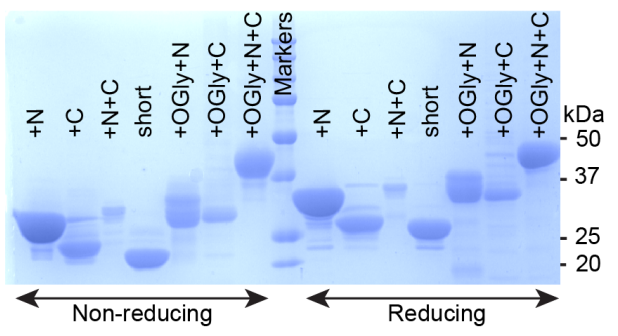

Figure 1. VWF, hydrodynamic flow, A1 activation, and A1 linkers. A) $\mathrm{N}$ and C-terminal linkage and domain organization of a VWF monomer in a VWF concatemer. Monomers are connected head-to-head and tail-to-tail. B) When exposed to elongational flow and tethered (black triangle) on a vessel wall, VWF concatemers extend to a linear shape. At higher elongational flow, which exerts higher mechanical tension along the length of the concatemer (highest at the tether point and zero at the downstream end) A1 undergoes transition from a low to a high affinity state as a consequence of tensile forces transmitted to it through its linkers. The disulfide bond between Cys1272 and Cys1458 is indicated with red S-S. C) A1 protein constructs studied here that differ in length of linkers and were expressed in E coli (not glycosylated) or in mammalian cells (O-glycosylated) (lollipops). The long-range disulfide bond is schematized in red. D) A1 constructs were subjected to SDS-PAGE and stained with Coomassie Blue. 
A1-paper v17-eLife.docx

et al., 2013). Despite multiple crystal structures of the A1 domain bound to GPIb, distinct conformational states of A1 that explain force-dependent regulation of A1 affinity for GPIb $\alpha$ have yet to emerge (Blenner et al., 2014; Dumas et al., 2004).

The force-responsive A1 domain is unusual among protein domains in being linked to neighboring domains through O-glycosylated, mucin-like segments (Fig. 1A, blue hashed lines). Tensile force exerted on A1 is transmitted through these linkers. It has been suggested that A1-flanking sequences (Auton et al., 2012; Interlandi et al., 2017; Ju et al., 2013; Miyata \& Ruggeri, 1999; Sugimoto et al., 1993) or domains (AponteSantamaria et al., 2015; Ulrichts et al., 2006) may shield the GPIb $\alpha$ binding epitope and thereby inhibit otherwise tight binding to GPIb. It was also proposed that the N- and C-linkers interact with each other and form an autoinhibitory module that masks A1 (Deng et al., 2017). A force-dependent signature for breakage of this module has been reported that correlates with the combined expected extension of the $\mathrm{N}$ and C-linkers (Arce et al., 2021). An alternative mechanism has also been proposed by which the N-linker could regulate A1 affinity, i.e., by regulating the relative stability of the A1 native and intermediate states. A1 has been found to have three states, native $(\mathrm{N})$, intermediate (I), and denatured (D), while the homologous A2 and A3 domains in VWF have only two states, native and denatured (Auton et al., 2007). Lower stability of the A1 native state correlates with higher affinity (Auton et al., 2012; Auton, Sowa, et al., 2010). This anti-correlation between A1 affinity and stability is also seen with von Willebrand disease type 2B gain-of-function mutations, which increase A1 affinity and decrease stability (Auton, Zhu, et al., 2010; Tischer et al., 2017). Conversely, the G1342S decrease-in-function type 2M von Willebrand disease mutation decreases A1 affinity for GpIb $\alpha$ and increases A1 stability (Auton et al., 2009). Here, to understand how binding of the VWF A1 domain to platelet GPIb $\alpha$ is regulated by its N- and Cterminal mucin-like linkers, we have made fundamental measurements of the effects of both the glycan and polypeptide moieties of these linkers on stability, thermodynamics, and ligand-binding affinity and kinetics of A1. Mucin-like regions in proteins have unique characteristics distinct from both intrinsically disordered polypeptide segments and folded domains. The bulky O-linked glycans which include sialic acid that are attached to threonine and serine residues in mucins are highly solvated, repel one another, and make mucins extended, with an average length of $\sim 2 \AA /$ residue (Clemetson, 1983; Woollett et al., 1985). Electron microscopy showed that D3 and A1 in 
A1-paper v17-eLife.docx

VWF, which are connected by the N-linker, have many possible orientations, and an interdomain distance as long as $\sim 7 \mathrm{~nm}$ (Zhou et al., 2011). A1 is mechanically stabilized by a long-range disulfide bond between Cys 1272 and Cys1458 (Figure 1B,C). Under tension, the core of A1 between these two cysteines, residues 1273-1457, is protected from complete unfolding. Only the portions of A1 external to this disulfide bond, residues 1238-1272 and 1458-1489, are directly subjected to the mechanical force transmitted through the spine of the VWF concatemer. Some folded portions of A1, including the C-terminal portion of the $\alpha 6$-helix, are external to the disulfide bond yet are in hydrogen bond communication with the folded portion internal to the disulfide. Here, we focus on the portions of the $\mathrm{N}$ and $\mathrm{C}$-linkers that lack well-defined structures and include the multiple serine and threonine residues that were found to be O-glycosylated during protein sequencing of native plasma VWF, including Thr-1248, Thr-1255, Thr-1256, and Ser-1263 in the N-linker (Titani et al., 1986). Mass spectrometry verified these assignments and showed a total of 8 sialic acids over the four sites (Solecka et al., 2016). We show that both the $\mathrm{N}$ and $\mathrm{C}$-linkers affect affinity, that both their polypeptide and O-glycan moieties are important, and that the N-linker affects stability and HDX of A1 including in specific regions internal to its disulfide.

\section{RESULTS}

Proteins. We compared the effect of the linkers N-terminal and C-terminal to A1, which separate A1 from D3 and A2, respectively, and which contain O-glycosylation sites that have been chemically identified in native VWF (Solecka et al., 2016; Titani et al., 1986) (Fig. 1). Because the linkers are O-glycosylated in mammalian Expi293 cells and not in E. coli, we expressed A1 protein constructs in both cell types in order to test the effect in some assays of both polypeptide and O-glycan components of the linkers (Fig. 1C). Slower migration in SDS-PAGE of the mammalian than corresponding bacterial A1 constructs confirmed O-glycosylation (Figure 1D). Furthermore, faster migration of all seven A1 constructs in non-reducing than reducing SDS-PAGE confirmed that all contained the long-range disulfide bond.

A1-GPIba binding kinetics and thermodynamics. Using bio-layer interferometry (BLI), we measured A1 association to and dissociation from GPIb $\alpha$ immobilized through a biotinylated C-terminal avitag to BLI sensor tips. A1 preparations were subjected to S200 gel filtration the day of each affinity measurement to remove 
bioRxiv preprint doi: https://doi.org/10.1101/2022.01.13.476208; this version posted January 13,2022 . The copyright holder for this preprint (which was not certified by peer review) is the author/funder, who has granted bioRxiv a license to display the preprint in perpetuity. It is made available under aCC-BY 4.0 International license.

A1-paper v17-eLife.docx

117 aggregates. Global fits at all analyte concentrations to a single on and off-rate for each A1 construct were good

118 (Fig. 2). In contrast, when gel filtration was omitted, data could not be fit to a single on and off-rate. Differences

119 among all seven $\mathrm{A} 1$ constructs in $150 \mathrm{mM} \mathrm{NaCl}$ showed that the linkers were of great importance in regulating 
bioRxiv preprint doi: https://doi.org/10.1101/2022.01.13.476208; this version posted January 13, 2022. The copyright holder for this preprint (which was not certified by peer review) is the author/funder, who has granted bioRxiv a license to display the preprint in perpetuity. It is made available under aCC-BY 4.0 International license.

A1-paper v17-eLife.docx
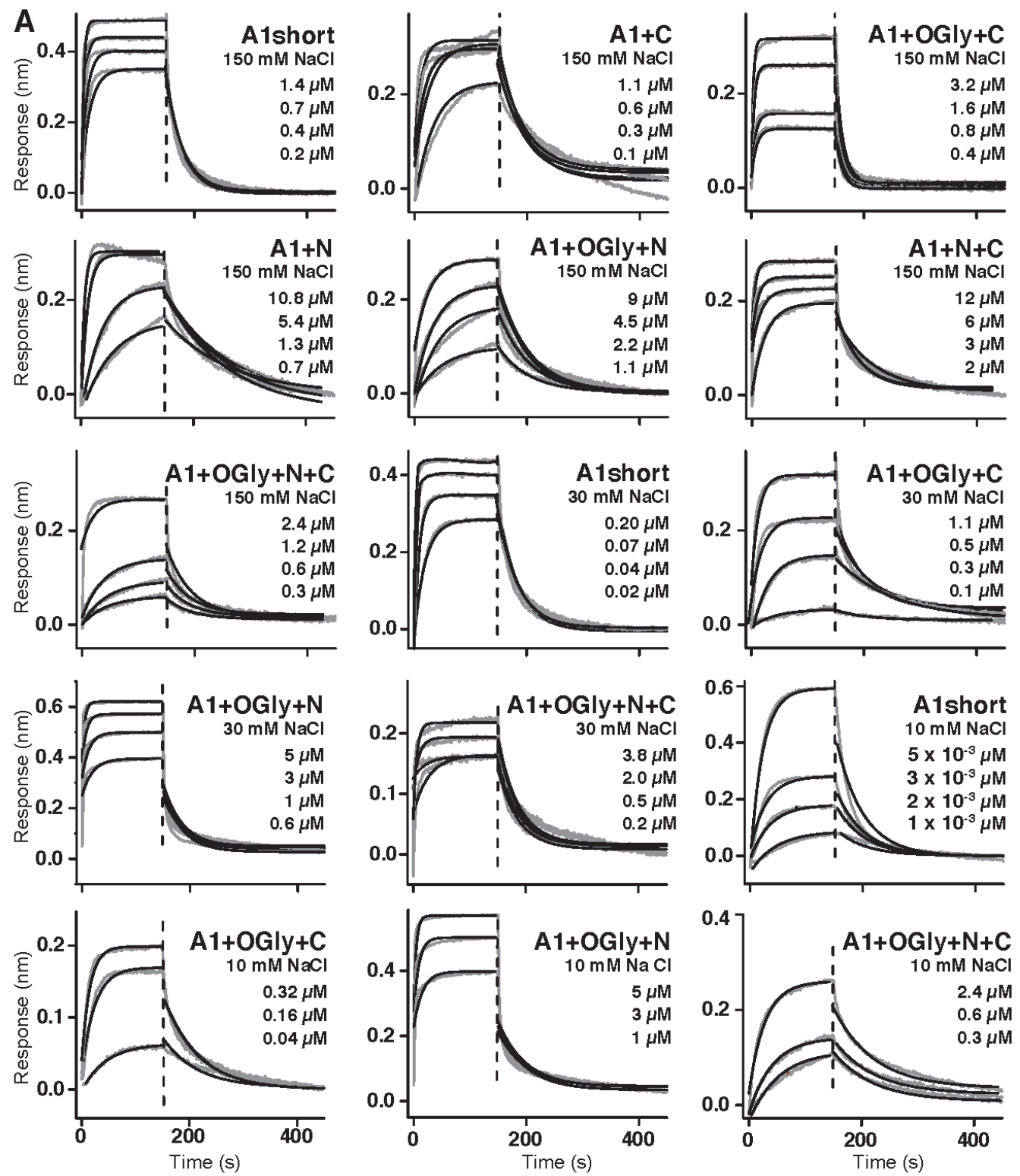

B $150 \mathrm{mM} \mathrm{NaCl}(\mathrm{l}=158 \mathrm{mM}) \quad 30 \mathrm{mM} \mathrm{NaCl}(\mathrm{l}=38 \mathrm{mM})$ $10 \mathrm{mM} \mathrm{NaCl}(\mathrm{l}=18 \mathrm{mM})$

\begin{tabular}{|c|c|c|c|c|c|c|c|c|c|}
\hline & $\begin{array}{l}\mathrm{K}_{\mathrm{D}} \\
\mathrm{nM}\end{array}$ & $\begin{array}{c}k_{\text {on }} \\
\mathrm{s}^{-1} \mathrm{M}^{-1} 10^{3} \\
\end{array}$ & $\begin{array}{c}k_{\text {off }} \\
s^{-1} 10^{-3}\end{array}$ & $\begin{array}{l}\mathrm{K}_{\mathrm{D}} \\
\mathrm{nM}\end{array}$ & $\begin{array}{c}k_{\text {on }} \\
\mathrm{s}^{-1} \mathrm{M}^{-1} 10^{3} \\
\end{array}$ & $\begin{array}{c}k_{\text {off }} \\
s^{-1} 10^{-3} \\
\end{array}$ & $\begin{array}{l}\mathrm{K}_{\mathrm{D}} \\
\mathrm{nM}\end{array}$ & $\begin{array}{c}k_{\text {on }} \\
\mathrm{s}^{-1} \mathrm{M}^{-1} 10^{3}\end{array}$ & $\begin{array}{r}k_{\text {off }} \\
s^{-1} 10^{-3} \\
\end{array}$ \\
\hline A1short & $180 \pm 20$ & $170 \pm 00$ & $31 \pm 3$ & $20 \pm 1$ & $980 \pm 470$ & $20 \pm 8$ & $4.7 \pm 0.4$ & $4470 \pm 160$ & $21 \pm 1$ \\
\hline $\mathrm{A} 1+\mathrm{OGly}+\mathrm{C}$ & $1020 \pm 60$ & $84 \pm 10$ & $85 \pm 4$ & $400 \pm 4$ & $44 \pm 6$ & $18 \pm 3$ & $100 \pm 10$ & $150 \pm 10$ & $16 \pm 0$ \\
\hline $\mathrm{A} 1+\mathrm{OGly}+\mathrm{N}$ & $7400 \pm 100$ & $2.2 \pm 0.2$ & $17 \pm 2$ & $760 \pm 50$ & $41 \pm 6$ & $31 \pm 3$ & $300 \pm 10$ & $65 \pm 6$ & $19 \pm 1$ \\
\hline $\mathrm{A} 1+\mathrm{OGly}+\mathrm{N}+\mathrm{C}$ & $9200 \pm 300$ & $3.7 \pm 1.2$ & $35 \pm 12$ & $1010 \pm 60$ & $29 \pm 0$ & $30 \pm 2$ & $420 \pm 40$ & $26 \pm 6$ & $11 \pm 2$ \\
\hline $\mathrm{A} 1+\mathrm{C}$ & $460 \pm 50$ & $37 \pm 17$ & $16 \pm 6$ & & & & & & \\
\hline $\mathrm{A} 1+\mathrm{N}$ & $780 \pm 160$ & $12 \pm 3$ & $8.8 \pm 0.1$ & & & & & & \\
\hline $\mathrm{A} 1+\mathrm{N}+\mathrm{C}$ & $1900 \pm 200$ & $31 \pm 19$ & $57 \pm 32$ & & & & & & \\
\hline
\end{tabular}

Figure 2. Effect of A1 linkers, their glycosylation, and ionic strength on GPIba binding kinetics. A) BLI traces in grey are shown for the indicated concentrations of the indicated A1 construct at the indicated $\mathrm{NaCl}$ concentration. In each panel, all A1 concentrations were fit globally to a one-site binding model to obtain a single $\mathrm{k}_{\text {on }}$ and $\mathrm{k}_{\text {off. }}$ Thin black lines show fits. Vertical dashed lines mark the beginning of the dissociation phase. B) Kinetic constants and derived $K_{D}$. Errors show difference from mean of $n=2$ independent experiments. 
A1-paper v17-eLife.docx

A1 affinity for GPIb $\alpha$ (Fig. 2). Comparisons to A1 short showed that non-glycosylated linkers in $\mathrm{A} 1+\mathrm{N}+\mathrm{C}$ lowered affinity by 10 -fold while the presence of glycosylated linkers in $\mathrm{A} 1+\mathrm{OGly}+\mathrm{N}+\mathrm{C}$ lowered affinity by 50 -fold. The $\mathrm{N}$-linker in $\mathrm{A} 1+\mathrm{N}$ lowered affinity by 4.3 -fold while the $\mathrm{C}$-linker in $\mathrm{A} 1+\mathrm{C}$ lowered 124 affinity by 2.5-fold. Glycosylation of the N-linker was also more important than the C-linker; the affinity of $\mathrm{A} 1+\mathrm{OGly}+\mathrm{N}$ was 10 -fold lower than $\mathrm{A} 1+\mathrm{N}$ while the affinity of $\mathrm{A} 1+\mathrm{OGly}+\mathrm{C}$ was only 2 -fold lower than $\mathrm{A} 1+\mathrm{C}$.

O-glycosylated linkers consistently lowered on-rates (Fig. 2B). Overall, the results showed that both the polypeptide linker moiety and the O-glycan moiety of A1 linkers contributed to lowering A1 affinity for GPIb $\alpha$, that the $\mathrm{N}$-linker was more important than the $\mathrm{C}$-linker in lowering affinity, and that the combined effect was very large at 50 -fold.

To test electrostatic contribution to binding affinity and on-rates, binding of A1 short and the three glycosylated constructs was additionally measured in $30 \mathrm{mM}$ and $10 \mathrm{mM} \mathrm{NaCl}$ (Fig. 2). Lowering $\mathrm{NaCl}$ concentration from $150 \mathrm{mM}$ to $10 \mathrm{mM}$ increased on-rates by an average of 17 -fold for the four constructs. The 134 greater average increase in affinity of 23-fold (Fig. 2B). Our results demonstrate that electrostatic 135 complementarity between the binding interfaces in the basic A1 (pI 9.2) and acidic GPIb $\alpha$ (pI 5.5) domains 136 (Huizinga et al., 2002) gives rise to electrostatic steering that speeds association kinetics. calorimetry (ITC). Although the GPIb $\alpha$ protein used in ITC lacked the avitag and its biotinylation, $\mathrm{K}_{\mathrm{D}}$

139 measurements in BLI and ITC were on average within 1.3-fold of one another and showed the same trends (Fig.

140 3). A1 short showed a 39-fold increase in affinity compared to $\mathrm{A} 1+\mathrm{OGly}+\mathrm{N}+\mathrm{C}$, the $\mathrm{N}$-linker was more important 141 than the C-linker, and the O-glycan moiety was more important than the polypeptide moiety in regulating affinity.

142 Binding of all A1 protein constructs to GPIb $\alpha$ releases heats that showed the reaction was endothermic, i.e., 143 entropically driven (Fig. 3B). The thermodynamics of A1- GPIb $\alpha$ binding showed entropy-enthalpy 144 compensation: the higher the entropic contribution to binding, the higher the enthalpic cost, with all seven 145 constructs following the same rank order for the entropic and enthalpic terms. Thus, the linkers affected both the 146 entropic and enthalpic components of GPIb $\alpha$ binding. 
A1-paper v17-eLife.docx
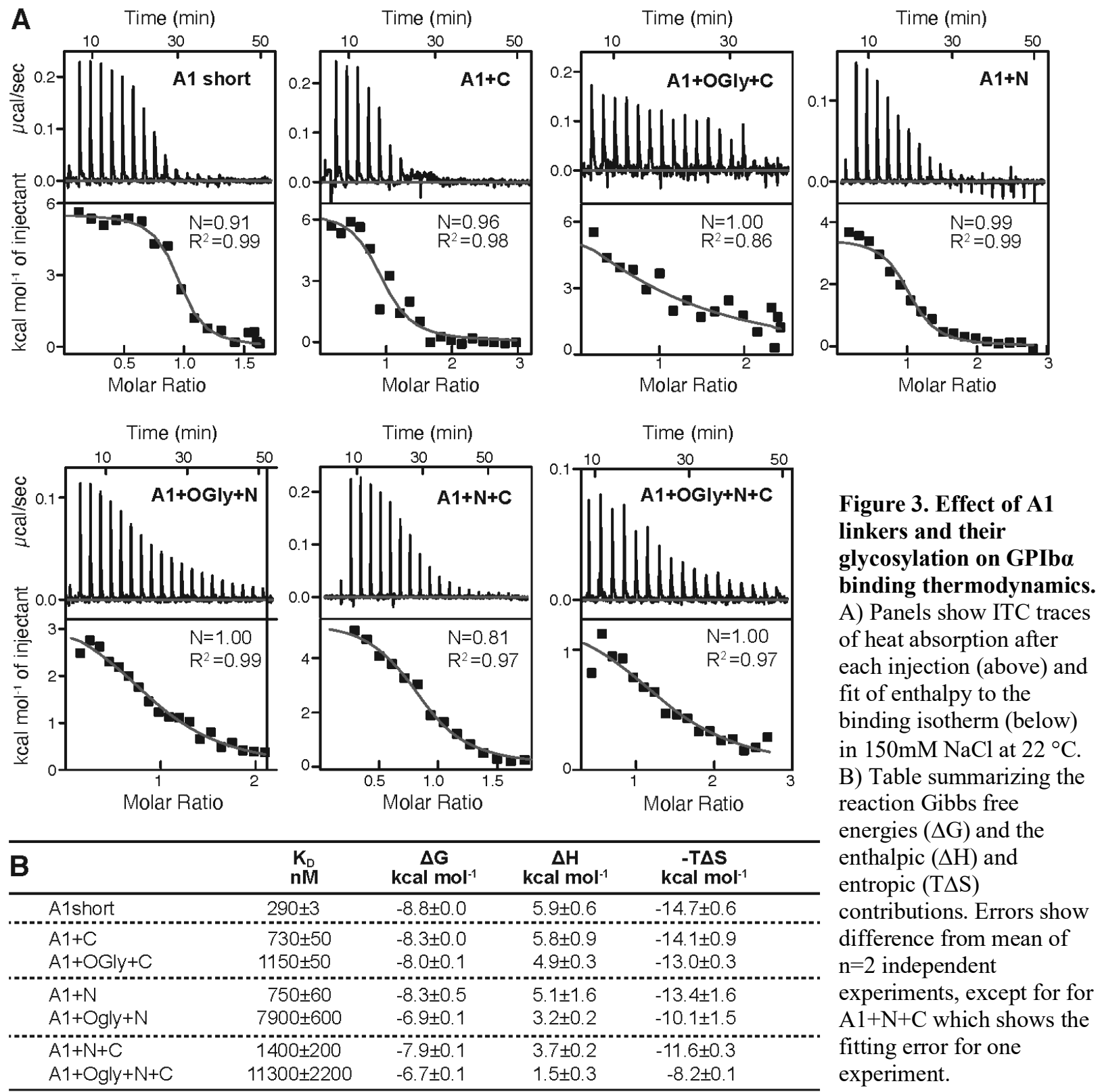

A1 stability and the thermodynamics of the intermediate state. The relative stabilities of A1 short and

148 the three O-glycosylated A1 constructs to denaturation by heat or urea were measured by tryptophan fluorescence,

149 whose emission maximum shifts to higher wavelength upon exposure to solvent during unfolding. The

150 fluorescence intensity ratio (FIR), $\mathrm{I}_{350} / \mathrm{I}_{330}$, showed that constructs had three states, i.e., exhibited two unfolding

151 transitions (Fig. 4A, B, and D). Constructs containing the $\mathrm{N}-$ linker, i.e. $\mathrm{A} 1+\mathrm{OGly}+\mathrm{N}+\mathrm{C}$ and $\mathrm{A} 1+\mathrm{OGly}+\mathrm{N}$, were

152 more stable to heat ( $\mathrm{Tm}$ of 53.2 and $53.3^{\circ} \mathrm{C}$ for the first transition, respectively) than constructs lacking the $\mathrm{N}$ -

153 linker, i.e. A1+OGly $+\mathrm{C}$ and $\mathrm{A} 1$ short (Tm of 49.9 and $50.7^{\circ} \mathrm{C}$ for the first transition, respectively) (Fig. $4 \mathrm{~A}$ and 
bioRxiv preprint doi: https://doi.org/10.1101/2022.01.13.476208; this version posted January 13, 2022. The copyright holder for this preprint (which was not certified by peer review) is the author/funder, who has granted bioRxiv a license to display the preprint in perpetuity. It is made available under aCC-BY 4.0 International license.

A1-paper v17-eLife.docx

154 B). These results suggest that the N-linker stabilizes the native state of A1 relative to the intermediate state.

155 Furthermore, all 4 constructs showed a second inflection point between 60 and $65^{\circ}$ (second peak or shoulder of

156 the derivative curve, Fig. 4B). These results suggested two-step unfolding behavior and thus that A1 has three

157 states, native (N), intermediate (I), and D (denatured) as previously observed (Auton et al., 2007).

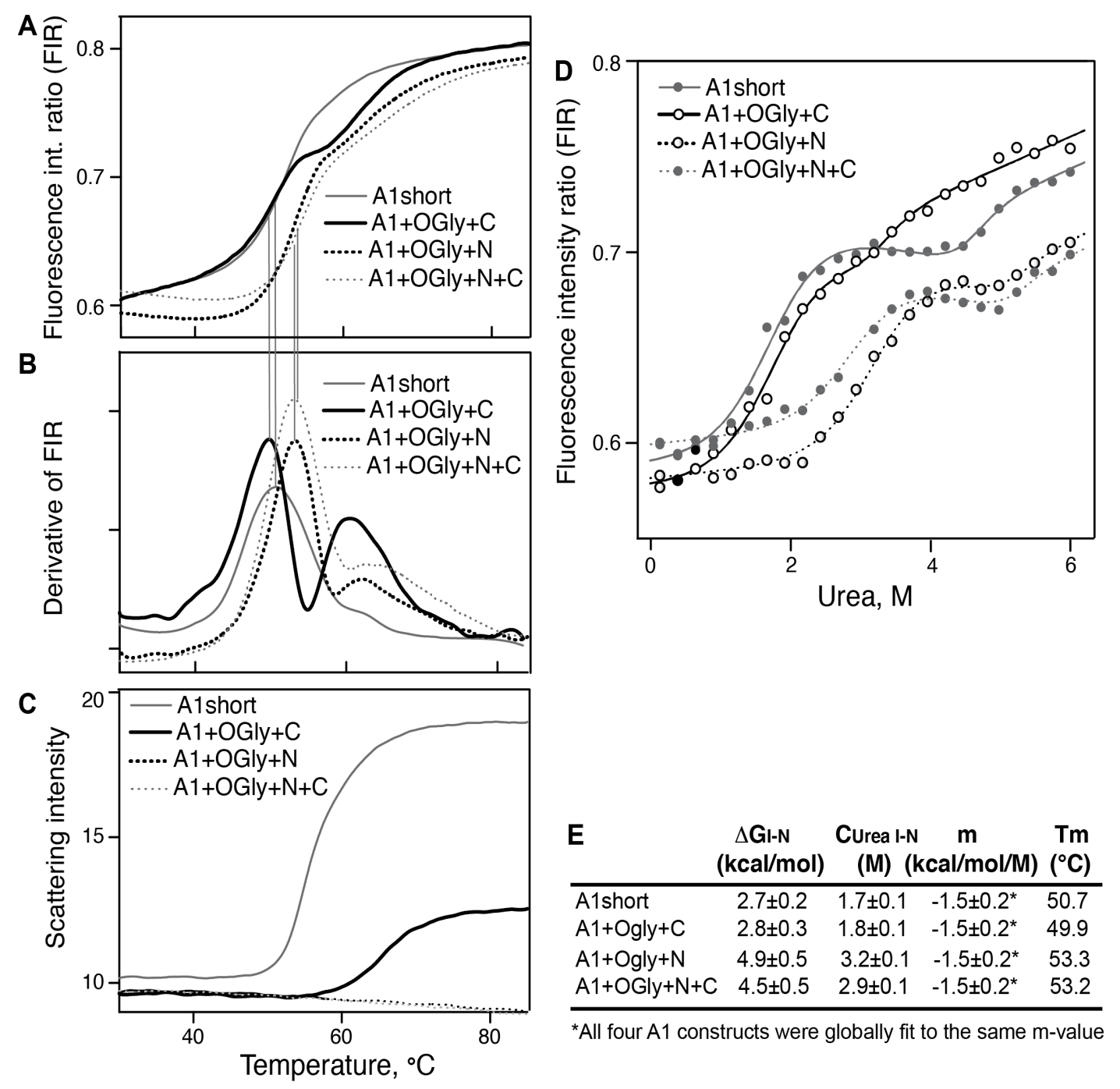

Figure 4. Stability of A1 constructs to heat and urea and free energy difference between the native and intermediate A1 states. A-C) Effect of heating from $30^{\circ}$ to $85^{\circ} \mathrm{C}$ on A1 stability and aggregation. A) Unfolding was measured by excitation of tryptophan at $275 \mathrm{~nm}$ and measuring the ratio of the fluorescence intensity at 350 and $330 \mathrm{~nm}\left(\mathrm{FIR}=\mathrm{I}_{350} / \mathrm{I}_{330}\right)$. B) The derivative of data in A (dFIR/dT) shows two unfolding transitions for each A1 construct and provides evidence for three states of A1: N, I, and U as described in Results. C) Backscattered light intensity as a measure of A1 aggregation. D) Unfolding of A1 by urea measured at $20^{\circ} \mathrm{C}$ by FIR as in panel A. Lines show fits to the three-state model of A1 unfolding as described in Methods and Results (see also: Source Data). E) Tabulation of the melting temperature of the native state (Tm) from panels A and B and the free energy difference between the native and intermediate states of $A 1\left(\Delta \mathrm{G}_{-\mathrm{N}}\right)$, the concentration of urea at which the I and $\mathrm{N}$ states are equally populated $\left(\mathrm{C}_{\text {urea I-N }}\right)$, and $\mathrm{m}$, from the fits in panel D. 
A1-paper v17-eLife.docx

A1 aggregation by heat was measured by backscattered light intensity. After the inflection point for the

intermediate state, A1 short began to aggregate (Fig. 4C compared to 4B). A1+OGlyc $+\mathrm{C}$ required higher

temperature for aggregation, which began to occur after the inflection point for the denatured state (Fig. 4C

161 compared to 4B). Strikingly, the O-glycosylated N-linker completely protected A1+OGly $+\mathrm{N}$ and $\mathrm{A} 1+\mathrm{OGly}+\mathrm{N}+\mathrm{C}$

162 from aggregation at temperatures up to $85^{\circ} \mathrm{C}$.

163 Denaturation in urea confirmed the existence of an intermediate state and was used to estimate the free 164 energy of the intermediate state relative to the native state, i.e., $\Delta \mathrm{G}_{\mathrm{I}-\mathrm{N}}$. The $\mathrm{A} 1$ constructs showed two separate 165 unfolding transitions, one between 1 to $4 \mathrm{M}$ Urea, and another above $5 \mathrm{M}$ urea (Fig. 4D). All constructs showed a 166 plateau in between, or in the case of $\mathrm{A} 1+\mathrm{Ogly}+\mathrm{C}$, followed a similar trend, but with a decrease in slope instead of a clear plateau. Similar 3-state unfolding curves were previously seen for a construct similar to $\mathrm{A} 1+\mathrm{N}+\mathrm{C}$ using circular dichroism (Auton et al., 2007). We fit the unfolding data to a three-state model. We assumed that all four $\mathrm{A} 1+\mathrm{OGly}+\mathrm{N}+\mathrm{C}$ than for A1 short and A1+OGly+C (Fig. 4E).

179 (Wales \& Engen, 2006). The O-glycosylated A1 constructs and A1 short were allowed to exchange their

180 backbone amide hydrogens for deuterium in $\mathrm{D}_{2} \mathrm{O}$ for varying periods of time, digested with pepsin, and the 181 kinetics of deuterium exchange were measured for 108 A1 peptides (91\% coverage, 5.8x redundancy, Fig. 5 and

182 Supplemental Figs. 1-5). HDX as a function of secondary structure and sequence position trended similarly for all 183 four constructs studied (shown for A1 short in Fig. 5A and for all in Supplementary Figs. 1-2). Fig. 5A shows 
bioRxiv preprint doi: https://doi.org/10.1101/2022.01.13.476208; this version posted January 13, 2022. The copyright holder for this preprint (which was not certified by peer review) is the author/funder, who has granted bioRxiv a license to display the preprint in perpetuity. It is made available under aCC-BY 4.0 International license.

A1-paper v17-eLife.docx

184

185

186

187

exchange for all 108 peptides at all time points, from $10 \mathrm{~s}$ to $4 \mathrm{~h}$. Over the $\mathrm{A} 1$ sequence from $\mathrm{N}$ to $\mathrm{C}$-terminal, the

least exchange was seen for the $\beta 1$-strand, the $\alpha 1$-helix, the $\beta 2$ and $\beta 3$-strands, the $\alpha 3$-helix, and the $\alpha 6$-helix,

which all had at least one peptide with less than $20 \%$ deuteration at $4 \mathrm{~h}$. These slowly exchanging secondary

structural elements neighbor one another and the GPIb $\alpha$ binding site on A1 (Fig. 5D).

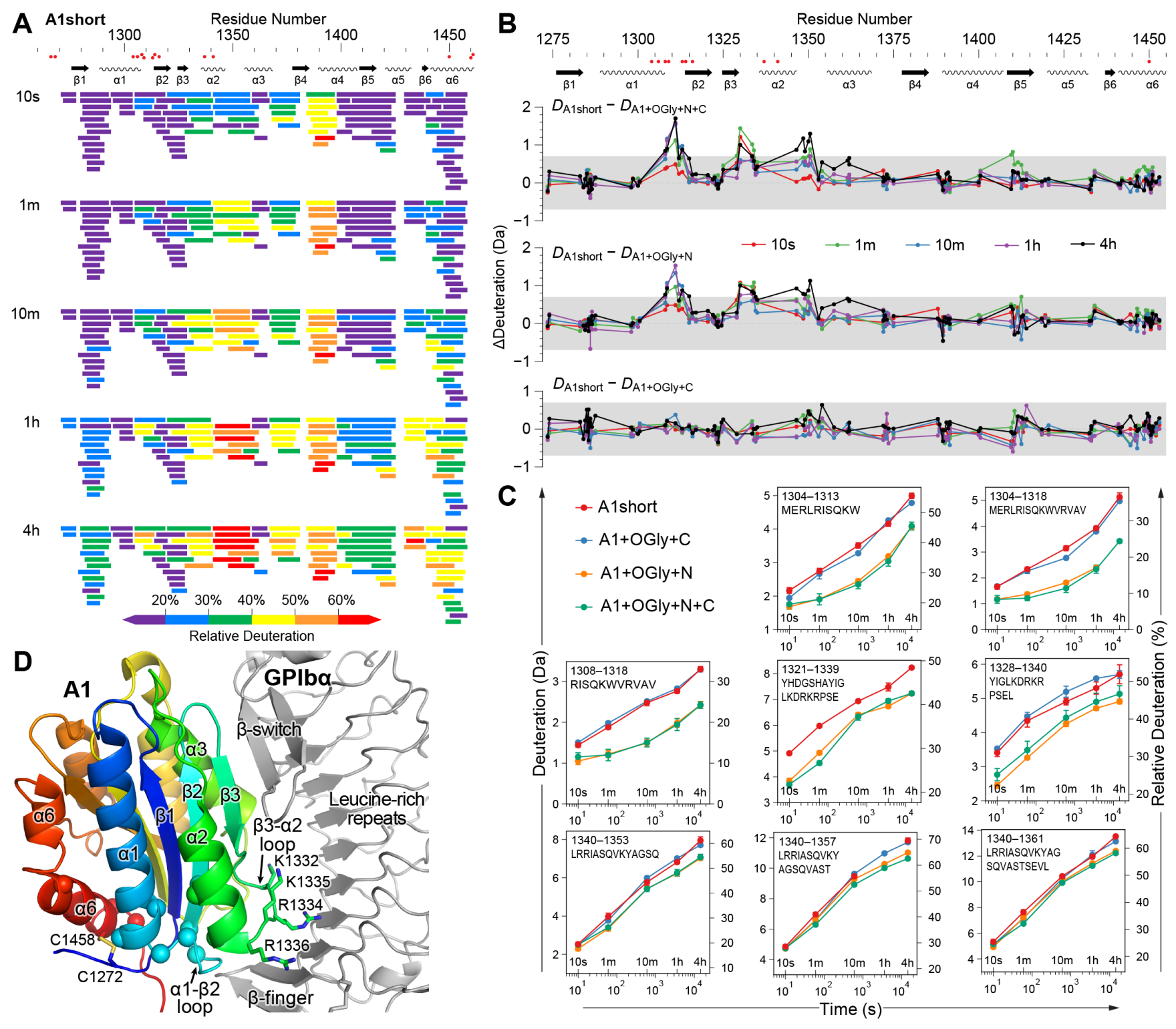

Figure 5. The N-linker decreases A1 dynamics measured by HDX. A) Relative deuterium exchange at all timepoints for A1 short as \% of the available amide backbone $\mathrm{H}$ atoms in each peptide, colored according to the key. Figure Supplements 1 and 2 show data for all constructs. B) Difference ( $\Delta)$ in HDX at all time-points of A1 short minus HDX for the other three constructs as indicated. In A) and B), residues with VWD type 2B mutations are shown below sequence numbers as red circles. C) Full HDX kinetics for selected peptides. Figure Supplements 3, 4, and 5 show data for all peptides. D) Structure of A1 bound to GPIb $\alpha$ (PDB 1SQ0). A1 is colored rainbow from N (blue) to C-terminus (red). Residues with VWD type $2 \mathrm{~B}$ mutations are shown as $\mathrm{C} \alpha$ atom spheres. Labeled residues are shown in stick. GPIb $\alpha$ is shown in silver, from the $\beta-$ finger to the $\beta$-switch. 
A1-paper v17-eLife.docx

constructs (Fig. 5B-C and Supplemental Figs. 3-5). The A1+OGly $+\mathrm{N}+\mathrm{C}$ and $\mathrm{A} 1+\mathrm{OGly}+\mathrm{N}$ constructs showed

significantly less deuterium exchange $(>0.7 \mathrm{Da})$ at almost all timepoints in peptides that were centered on the $\alpha 1$ -

$191 \beta 2$ loop and the $\beta 3-\alpha 2$ loop. These loops locate near to GPIb $\alpha$ (Fig. 5B-D). We also observed reduced exchange

192 in the $\alpha 2-\alpha 3$ loop, but the most meaningful difference was only seen at the $4 \mathrm{~h}$ timepoint. The $\alpha 1-\beta 2$ loop is

193 nearby the long-range disulfide and in a region with multiple gain of function VWD type 2B mutations (Fig. 5D).

194 The $\beta 3-\alpha 2$ loop is near to GPIb $\alpha$ and has four basic residues but they are not close enough for optimal interaction 195 with acidic residues in the GPIb $\alpha$ leucine-rich repeats.

The HDX data showed no significant HDX differences between A1 short and A1+OGly+C. Further, the magnitude of HDX differences between A1 short and both $\mathrm{A} 1+\mathrm{OGly}+\mathrm{N}+\mathrm{C}$ and $\mathrm{A} 1+\mathrm{OGly}+\mathrm{N}$ was very similar.

However, while $\mathrm{A} 1+\mathrm{OGly}+\mathrm{N}+\mathrm{C}$ and $\mathrm{A} 1+\mathrm{OGly}+\mathrm{N}$ were similar to one another in $\mathrm{HDX}$, they both exchanged less native states relative to the intermediate states (Figure 4), which showed that $\mathrm{A} 1+\mathrm{OGly}+\mathrm{N}+\mathrm{C}$ and $\mathrm{A} 1+\mathrm{OGly}+\mathrm{N}$

were similarly stable and more stable than A1 short and A1+OGly $+\mathrm{C}$, which were also similar in stabiliy.

\section{DISCUSSION}

Among domains in proteins, the A1 domain of VWF is highly unusual in being separated from that originates from hydrodynamic force on VWF concatemers and bound platelets. Here, we have investigated the effects of these linkers on A1 thermodynamics and function in binding to its ligand, GPIb $\alpha$. Previous studies have examined the effect of the $\mathrm{N}$-terminal linker or both linkers on various types of quantitative or nonquantitative binding assays and thermodynamics and found inhibitory effects on GPIb $\alpha$ binding from adding the

211 Interlandi et al., 2017; Ju et al., 2013; Miyata \& Ruggeri, 1999; Nakayama et al., 2002; Tischer et al., 2017;

212 Tischer et al., 2014). We found that both the N and C-linker decreased A1 affinity for GPIba and that for both the 
$213 \mathrm{~N}$ and C-linker, O-glycosylated linkers decreased affinity more than polypeptide linkers. For the C-linker, both

214 the O-glycan and polypeptide moieties were similar in importance, giving $\sim 2.2$-fold decreases in affinity each,

215 while for the N-linker, the O-glycan component was more influential (9.5-fold) than the polypeptide alone (4.3-

216 fold). While adding O-glycosylated linkers on the $\mathrm{N}$ and C-terminal ends of A1 lowered affinity substantially (51-

217 fold and 6-fold, respectively), the presence of both O-glycosylated linkers lowered binding little compared to the

218 presence of the N-linker alone (1.2-fold). The separate contributions of the polypeptide and glycan moieties of the

219 A1 N and C-linkers had not previously been examined; however, O-glycosylation of both linkers together was

220 reported to decrease affinity from $3.9 \mu \mathrm{M}$ to $32 \mu \mathrm{M}$ (Tischer et al., 2020). While these reported affinities differ

221 from ours by 2 to 3 -fold, they agree in terms of the affinity difference caused by O-glycosylation. Kinetic

222 measurements showed that the effect of both the polypeptide and O-glycan components of the linkers was

223 primarily on-rate driven. Overall, among the seven constructs, on-rates varied by up to 80-fold while off-rates

224 varied up to 10 -fold.

Rapid binding is especially important for proteins that function in hemostasis; electrostatics can help

orient proteins for proper binding before they contact one another, as previously demonstrated using the ionic

strength dependence of binding of soluble GPIb $\alpha$ to VWF tethered to the wall of a flow chamber (Fu et al., 2017).

Our kinetic measurements in $10 \mathrm{mM}$ compared to $150 \mathrm{mM} \mathrm{NaCl}$ showed a 20 -fold increase in affinity for

$\mathrm{A} 1+\mathrm{OGly}+\mathrm{N}+\mathrm{C}$ largely driven by a 7-fold increase in $\mathrm{k}_{\mathrm{on}}$, while VWF tethered to a flow chamber showed a 130-

fold increase in affinity driven by an 11-fold increase in $\mathrm{k}_{\mathrm{on}}$.

In $150 \mathrm{mM} \mathrm{NaCl}$, the high affinity state of tethered, mechanically tensioned VWF had an affinity of 80

$232 \mathrm{nM}$ for GPIb $\alpha$, compared to the $\mathrm{K}_{\mathrm{d}}$ values of $180 \mathrm{nM}$ for $\mathrm{A} 1$ short and 9,200 $\mathrm{nM}$ for $\mathrm{A} 1+\mathrm{Og} l \mathrm{y}+\mathrm{N}+\mathrm{C}$ measured

233 here. Introduction of two VWD mutations into A1 was shown to increase affinity for GPIb $\alpha$ by 10-fold (Blenner

234 et al., 2014). However, even though such a mutant would be expected to increase the affinity of the A1 short

235 construct to a higher level than found for mechanically-tensioned A1 in intact VWF, a crystal structure of A1

236 short with two VWD mutations bound to GPIb $\alpha$ revealed only minor differences from a WT-GPIb $\alpha$ crystal

237 structure (Blenner et al., 2014). Mechanical tension on one hand and introduction of VWD mutations in the

238 absence of tension and removal of the $\mathrm{N}$ and $\mathrm{C}$-linkers on the other hand may have different effects on the 
bioRxiv preprint doi: https://doi.org/10.1101/2022.01.13.476208; this version posted January $13,2022$. The copyright holder for this preprint

(which was not certified by peer review) is the author/funder, who has granted bioRxiv a license to display the preprint in perpetuity. It is made available under aCC-BY 4.0 International license.

A1-paper v17-eLife.docx

structure of the A1 domain, consistent with the hypothesis that A1 short with two VWD mutations bound to GPIb $\alpha$ did not reveal an A1 high affinity state, despite an affinity for GPIb $\alpha$ comparable to that seen with mechanically-tensioned VWF (Blenner et al., 2014).

We buttressed BLI affinity measurements here with ITC measurements of affinity and binding energies. While affinity measurements in the literature on essentially identical A1 fragments can differ up to 15 -fold from those reported here (Huizinga et al., 2002), affinity measurements here on seven different Al constructs by BLI and ITC were all within 1.6 to 1.04 -fold of one another. We found it was necessary to remove aggregates from A1 preparations by gel filtration immediately prior to BLI measurements to avoid heterogeneous kinetics that required two on and off-rates to fit, which appear in some of the literature on A1 binding to GPIb $\alpha$ (Arce et al., 2021; Tischer et al., 2017). In general, measurements in the liquid phase are more accurate than those in solid/liquid phases such as SPR and BLI, where a small amount of an avid aggregate can dominate binding kinetics.

We are unaware of previous thermodynamic measurements of A1 and GPIb $\alpha$ binding. ITC results show that the interaction of GPIb $\alpha$ with all seven A1 constructs was endothermic with a large entropic term that ranged from -8.2 to $-14.7 \mathrm{kcal} / \mathrm{mol}$ at $22^{\circ} \mathrm{C}$. Among all seven A1 constructs, the enthalpy and entropy terms were highly correlated, so that their rank orders were identical. Entropy-driven binding of proteins is usually attributed to the increase in water entropy when waters are released from hydrophobic binding interfaces (Richards, 1977).

Our HDX studies revealed that the O-glycosylated N-linker has a significant effect in stabilizing the $\alpha 1$ $\beta 2, \beta 3-\alpha 2$, and the $\alpha 2-\alpha 3$ loops, as shown by less deuterium incorporation. Previous HDX studies have shown that destabilizing A1 by reducing and alkylating its long-range disulfide, introducing VWD Type 2B mutations, or omitting N-linker residues 1238-1260 increase HDX in the same regions (Deng et al., 2018; Deng et al., 2017; Tischer et al., 2017; Tischer et al., 2014). The finding that stands out from previous reports, which did not study the C-linker individually in HDX, is that in contrast to the N-linker, the C-linker did not significantly affect HDX in any of these regions.

We directly measured the stability of A1 by measuring its unfolding by heat and urea. We found evidence for three states by both techniques, consistent with a previous finding of an intermediate state that is hypothesized 
bioRxiv preprint doi: https://doi.org/10.1101/2022.01.13.476208; this version posted January $13,2022$. The copyright holder for this preprint (which was not certified by peer review) is the author/funder, who has granted bioRxiv a license to display the preprint in perpetuity. It is made available under aCC-BY 4.0 International license.

A1-paper v17-eLife.docx

265 to represent a state with high affinity for GPIba (Auton, Sowa, et al., 2010; Tischer et al., 2017; Tischer et al., 266 2014). A plateau between the first and second transition clearly demonstrated the existence of the intermediate 267 state for three of our four constructs, in contrast to the decrease in slope seen previously. This difference was 268 likely due to measurement here of the fluorescence of the single tryptophan residue, Trp-1313 in A1, as opposed 269 to circular dichroism, which measures contributions from all A1 secondary structures. Trp-1313 is in the $\alpha 1-\beta 2$ 270 loop that has HDX dynamics that are sensitive to the presence of the N-linker, locates near the GPIb $\alpha$-finger, is 271 mutated in VWD type 2B, and appears to be a more discrete reporter of A1 conformational state than circular 272 dichroism. Heat and urea denaturation had similar linker-dependent effects on stability of A1. A1-Ogly $+\mathrm{N}$ and $273 \mathrm{~A} 1-\mathrm{Ogly}+\mathrm{N}+\mathrm{C}$ were each $\sim 3^{\circ} \mathrm{C}$ more stable than $\mathrm{A} 1$ short and $\mathrm{A} 1-\mathrm{Og} l y+\mathrm{C}$. Likewise, A1-Ogly $+\mathrm{N}$ and A1274 Ogly $+\mathrm{N}+\mathrm{C}$ each had native $(\mathrm{N})$ states that were relatively more stable than their intermediate (I) states, by $\sim 2$ $275 \mathrm{kcal} / \mathrm{mol}$, than found for A1 short and A1+Ogly + C. Additionally, the N-linker was sufficient to completely 276 protect A1 against heat-induced aggregation up to $85^{\circ} \mathrm{C}$. Since physiological tensile force on A1 may induce the I 277 state, which could make A1 and with it an entire VWF concatemer susceptible to aggregation, one of the several 278 important physiological roles of the N-linker and its O-glycosylation may be to protect it from aggregation. The 279 neighboring A2 domain in VWF can be completely and reversibly unfolded by tensile force and can also be 280 reversibly heated to $90^{\circ} \mathrm{C}$ without aggregation in the presence of its O-linked N-linker (the C-linker of A1) and its 281 C-linker (Xu \& Springer, 2013; Zhang et al., 2009), which may have a similar protective role physiologically to 282 prevent aggregation during physiological partial (A1) and full (A2) unfolding.

Our results on the effects of the O-linked $\mathrm{N}$ and C-linkers on affinity and stability differ. The C-linker 284 decreased A1 affinity for GPIb $\alpha$ in two different measures, BLI and ITC, but had no effect on A1 stability as 285 measured by HDX, melting temperature, and the relative stability of the A1 $\mathrm{N}$ and I states in urea denaturation 286 experiments. These results suggest that the C-linker decreases affinity by direct mechanisms such as by steric or 287 electrostatic repulsion. O-glycans are decorated with sialic acid, which would repel negatively charged GPIba. In 288 contrast to the C-linker, the N-linker not only decreased affinity but also increased A1 stability as shown by 289 significantly decreased HDX, increased melting temperature, and increased stability of the N state relative to the I 290 state. The $\sim 2 \mathrm{kcal} / \mathrm{mol}$ difference in $\Delta \mathrm{G}$ between the $\mathrm{N}$ and I state for $\mathrm{A} 1+\mathrm{Og} l \mathrm{y}+\mathrm{N}$ compared to A1 short 
A1-paper v17-eLife.docx

corresponds to a $\sim 30$-fold difference in population of the I state. Thus, if the I state was the high affinity state, much of the 40-fold difference in affinity between the I and $\mathrm{N}$ states could be accounted for by the shift in equilibrium toward the native state caused by the N-linker, and the remainder could be caused by steric and 294 electrostatic repulsion of GPIb $\alpha$. In VWF concatemers, the $\Delta \mathrm{G}$ required for activation by mechanical tension of 295 the high affinity state was measured as $1.9 \mathrm{kcal} / \mathrm{mol}$ (Fu et al., 2017), considerably lower than the difference in 296 energy between the I and $\mathrm{N}$ states measured for $\mathrm{A} 1+\mathrm{Ogly}+\mathrm{N}+\mathrm{C}$ here of $4.7 \mathrm{kcal} / \mathrm{mol}$. These differences suggest 297 that the directional nature of energy input by mechanical tension allows for more efficient activation of A1 than 298 urea denaturation and may induce a distinct and less disordered intermediate state.

Three different mechanisms have been proposed for how the linkers affect A1 binding to GPIb $\alpha$. The proposal that the N-linker and C-linker associate with one another to form an autoinhibitory module (Deng et al., 2018; Deng et al., 2017) is not supported by our data that show that the N-linker alone is sufficient to inhibit binding of A1 to GPIb $\alpha$. Furthermore, we find that the N-linker and C-linker are not synergistic and to the contrary, have much less than additive effects on lowering binding affinity. It also has been proposed that residue Asp-1261 in the N-linker interacts with basic residues in the A1 domain to stabilize a low affinity state of A1 (Interlandi et al., 2017). While our results do not bear on this mechanism, they do demonstrate that the O-linked glycans within the N-linker are sufficient to strongly inhibit binding of A1 to GPIb $\alpha$. Finally, Auton and colleagues have described an intermediate state of A1 that is proposed to correspond to an activated high affinity

313 The flexible $\beta$-finger in the N-terminal cap of GPIb $\alpha$ associates with A1 over a smaller region, including the $\alpha 1$ -

$314 \beta 2$ loop, with few specific contacts that vary among GPIb $\alpha$-complexes (Fig 5D). Strain in A1 upon binding GPIb $\alpha$ 315 causes shifts in some residues in the $\alpha 1-\beta 2$ loop and Cys-1272 away from GPIb $\alpha$. Furthermore, the hydrogen 316 bond between the backbone of Cys-1272 and the backbone of Arg-1308 (a residue often mutated in VWD), which 
A1-paper v17-eLife.docx

317 is conserved in all structures of the isolated A1 domain, is lost in all A1-GPIb $\alpha$ complex structures. This loss

318 admits a water molecule to the hydrophobic core of A1. These structural observations begin to define a pathway

319 for conformational communication between the N-linker and regions of A1 that change upon GPIba-binding,

320 including the $\alpha 1-\beta 2$ loop, which showed increased HDX dynamics in the absence of the N-linker. Crystal

321 structures of A1 diverge prior to residue 1273, suggesting that the O-glycosylated N-linker of A1 (defined in our

322 experiments as residues 1238-1263) is natively disordered. It is now well established that natively disordered

323 regions in proteins frequently have important roles in regulating protein allostery (Motlagh et al., 2014). We

324 speculate that in the intermediate state, A1 would reshape to enable closer approach to the concave, acidic surface

325 of GPIb $\alpha$ of more A1 basic residues, such as those in its $\beta 3-\alpha 2$ loop shown in stick in Fig. 5D.

In summary, our results show that the A1 N-linker, but not the C-linker, increases the stability of the A1

328 discussed structural evidence for a pathway for communication from the N-linker to regions that are known to

329 change structurally upon GPIb $\alpha$ binding and also have backbone motions that are influenced by the N-linker as

330 shown by HDX. Additionally, our results suggest that the C-linker influences affinity for GPIb $\alpha$ by steric and

331 possibly charge repulsion. The N-linker may repel GPIb $\alpha$ as well, in addition to regulating A1 conformation.

\section{MATERIALS AND METHODS}

Glycosylated proteins. Human VWF A1 domain constructs as shown in Figure 1C (pre-pro-VWF amino

334 acid residue numbering), beginning with residue 1238 or 1264 and ending with residue 1469 or 1489 and

335 followed with a C-terminal 6xHis tag were cloned into a bicistronic IRES-GFP expression vector, ET8 (Zhou \&

336 Springer, 2014) and transfected into Expi293F cells using lipofectamine reagent (Invitrogen). Stable transfectants

337 were selected in the presence of $500 \mu \mathrm{g} / \mathrm{mL} \mathrm{G418} \mathrm{(Geneticin)} \mathrm{and} \mathrm{subjected} \mathrm{to} 2$ rounds of fluorescence-activated

338 cell sorting. In each sort, the 8\% most fluorescent cells were expanded in Expi293 expression medium. Culture

339 supernatants were harvested after 5 days, supplemented with $20 \mathrm{mM}$ HEPES pH 7.4 and $0.2 \mathrm{mM} \mathrm{NiCl}$ (final

340 concentration), and loaded onto a Ni-NTA agarose column by gravity ( $2 \mathrm{~mL}$ Ni-NTA agarose beads per $500 \mathrm{~mL}$

341 of culture supernatant). The column was pre-equilibrated in Washing Buffer (20 mM HEPES pH 7.4, $150 \mathrm{mM}$ 
bioRxiv preprint doi: https://doi.org/10.1101/2022.01.13.476208; this version posted January $13,2022$. The copyright holder for this preprint (which was not certified by peer review) is the author/funder, who has granted bioRxiv a license to display the preprint in perpetuity. It is made available under aCC-BY 4.0 International license.

A1-paper v17-eLife.docx

$342 \mathrm{NaCl}, 0.2 \mathrm{mM} \mathrm{NiCl})$. After loading the supernatant, the column was washed with 5 column volumes of Washing 343 Buffer followed by 10 column volumes of $20 \mathrm{mM}$ HEPES, $1 \mathrm{M} \mathrm{NaCl}, 16 \mathrm{mM}$ imidazole, $0.2 \mathrm{mM}$ NiCl. Protein 344 was eluted with $20 \mathrm{mM}$ HEPES, $150 \mathrm{mM} \mathrm{NaCl}$ and $300 \mathrm{mM}$ imidazole, and further purified by Superdex 200 345 (GE Healthcare) size-exclusion chromatography in $20 \mathrm{mM}$ HEPES, $150 \mathrm{mM} \mathrm{NaCl}, \mathrm{pH}$ 7.5.

346 Wild-type GPIba, residues 1-290 of the mature protein with a C-terminal His 6 tag, with or without an 347 intervening Avi-tag sequence (GLNDIFEAQKIEWHE), was purified from culture supernatant of 293 stable 348 transfectants (Blenner et al., 2014) by Ni-NTA affinity chromatography and Superdex 200 size-exclusion as 349 above.

Non-glycosylated proteins. The cDNA sequence encoding A1 beginning with residue 1238 or 1264 and ending with residue 1469 or 1486 (Figure 1C) was cloned into the pET32a vector with a thioredoxin fusion protein (LaVallie et al., 1993) and a TEV cleavage site at its N-terminus and a 6xHis tag at its C-terminus. Proteins were expressed in SHuffle cells (Lobstein et al., 2012), which were grown at $37{ }^{\circ} \mathrm{C}$ in LB medium, induced at an $\mathrm{A} 600$ of 0.8 by the addition of $1 \mathrm{mM}$ IPTG at $25^{\circ} \mathrm{C}$, and collected after $20 \mathrm{~h}$ by centrifugation. Cells were lysed in a French press at $4{ }^{\circ} \mathrm{C}$ in $20 \mathrm{mM}$ HEPES (pH 7.4), $150 \mathrm{mM} \mathrm{NaCl}$. The lysate was centrifuged at 17,000xg at $4{ }^{\circ} \mathrm{C}$ for $40 \mathrm{~min}$. Ni-NTA agarose beads were added to the supernatant containing soluble A1 and shaken overnight at $4{ }^{\circ} \mathrm{C}$ in $40 \mathrm{~mL}$ Falcon tubes $(1.5 \mathrm{~mL}$ beads / $40 \mathrm{~mL}$ supernatant). Beads were centrifuged at 2500 RPM for $5 \mathrm{~min}$ and re-suspended in 10mL buffer (20 mM HEPES, $150 \mathrm{mM} \mathrm{NaCl}, \mathrm{pH} 7.4$ ) per tube and 359 vortexed for $2 \min \left(1^{\text {st }}\right.$ washing step). After two more washing steps, 5 cleaning steps were performed following 360 the same procedure but with $20 \mathrm{mM}$ HEPES, $1 \mathrm{M} \mathrm{NaCl}$ and $16 \mathrm{mM}$ imidazole. The beads were then packed into a 361 column and eluted with $20 \mathrm{mM}$ HEPES, $150 \mathrm{mM} \mathrm{NaCl}, 300 \mathrm{mM}$ imidazole by gravity. The eluate was mixed with 362 Tobacco Etch Virus (TEV) protease (A1:TEV mass ratio of 10:1) and dialysed against $20 \mathrm{mM}$ HEPES, $150 \mathrm{mM}$ $363 \mathrm{NaCl}$ overnight at $4^{\circ} \mathrm{C}$. The thioredoxin-cleaved $\mathrm{A} 1$ was centrifuged for $10 \mathrm{~min}$ at $13,000 \mathrm{rpm}$ to remove 364 precipitate. The supernatant was further purified by heparin column (HiTrap Heparin HP, GE Healthcare), washed 365 with $20 \mathrm{mM}$ HEPES, $350 \mathrm{mM} \mathrm{NaCl}$ and eluted with $20 \mathrm{mM}$ HEPES, $800 \mathrm{mM} \mathrm{NaCl}$. Finally, the protein was 
bioRxiv preprint doi: https://doi.org/10.1101/2022.01.13.476208; this version posted January $13,2022$. The copyright holder for this preprint (which was not certified by peer review) is the author/funder, who has granted bioRxiv a license to display the preprint in perpetuity. It is made available under aCC-BY 4.0 International license.

A1-paper v17-eLife.docx

Storage and re-purification. All proteins were stored at $-80^{\circ} \mathrm{C}$ and subjected to a second round of size

exclusion chromatography on the day of measurements. This was essential to prevent protein aggregates from

contributing to affinity and kinetics measurements, i.e., to obtain data that can be reliably fitted with a 1:1 binding

model.

Kinetic binding measurements. The GPIb $\alpha$ used for kinetic measurements contained an N-terminal Avitag which was biotinylated using a BirA biotin-protein ligase kit (Cat \#BirA500, Avidity, Aurora, CO). Biolayer interferometry (BLI) used Octet RED384 instrument and software (ForteBio). Streptavidin-functionalized sensors

Northampton, MA). The ionic strength of 20 mM HEPES, pH 7.5 was calculated using

https://www.liverpool.ac.uk/pfg/Research/Tools/BuffferCalc/Buffer.html.

Isothermal calorimetry (ITC). Proteins were dialyzed overnight against $150 \mathrm{mM} \mathrm{NaCl}, 20 \mathrm{mM}$ Tris-

$\mathrm{HCl} \mathrm{pH} 7.5$, degassed, and centrifuged at $20,000 \times \mathrm{g}$ for $10 \mathrm{~min}$. GPIb $\alpha(250 \mu \mathrm{M}$ except $550 \mu \mathrm{M}$ with

$\mathrm{A} 1+\mathrm{OGly}+\mathrm{N}+\mathrm{C})$ was titrated into an $\mathrm{A} 1$ protein solution $(22 \mu \mathrm{M}$ except $50 \mu \mathrm{M}$ with $\mathrm{A} 1+\mathrm{OGly}+\mathrm{N}+\mathrm{C})$ in a

MicroCal iTC200 (GE Healthcare Life Sciences). A priming injection of $0.4 \mu \mathrm{L}$ (not included in data analysis) was followed by $2 \mu \mathrm{L}$ injections every $180 \mathrm{~s}$. Data averaged over 2-s windows were analyzed using Originlab 7. urea, and $(80-x) \mu \mathrm{L}$ of water, where $\mathrm{x}$ gave final urea concentrations of $0.135-6 \mathrm{M}$ in 24 concentration steps in 
Fluorescence intensity ratio $(F I R)$, emission intensities at $350 \mathrm{~nm}$ over $330 \mathrm{~nm}$, was fit as a function of urea concentration to a 3-state transition model using the Linear Extrapolation Method (Santoro \& Bolen, 1988). FIR at each urea concentration $\left(C_{\text {urea }}\right)$ is modeled as the population weighted contribution from the native state $(\mathrm{N})$, intermediate state (I), and the denatured state (D): $F I R\left(C_{\text {urea }}\right)=F I R_{\mathrm{N}} * P_{\mathrm{N}}+F I R_{\mathrm{I}} * P_{\mathrm{I}}+F I R_{\mathrm{D}} * P_{\mathrm{D}}$ where $F I R_{\mathrm{N}}, F I R_{\mathrm{I}}$ and $F I R_{\mathrm{D}}$ represent the linear baseline for the N, I and D states, respectively, which can be expressed as $F I R_{\mathrm{j}}=$ $b_{\mathrm{j}}+s_{\mathrm{j}} \cdot C_{\mathrm{Urea}}$, with $b_{\mathrm{j}}$ and $s_{\mathrm{j}}$ as intercept and slope of the $\mathrm{j}$ state. $P_{\mathrm{N}}, P_{\mathrm{I}}$ and $P_{\mathrm{D}}$ represent the population of N, I and

D states at each urea concentration, respectively. The population of state $\mathrm{j}\left(P_{\mathrm{j}}\right)$ in the system can be related to the

400 free energy of each state $(\mathrm{N}, \mathrm{I}, \mathrm{D})$ based on the Boltzmann distribution, $P_{j}=\frac{\operatorname{Exp}\left(-\frac{\Delta G_{j}}{\mathrm{R} \cdot T}\right)}{\operatorname{Exp}\left(-\frac{\Delta G_{N}}{\mathrm{R} \cdot T}\right)+\operatorname{Exp}\left(-\frac{\Delta G_{I}}{\mathrm{R} \cdot T}\right)+\operatorname{Exp}\left(-\frac{\Delta G_{D}}{\mathrm{R} \cdot T}\right)}$, where R 401 is the gas constant, and $T$ is absolute temperature of the system. With the $\mathrm{N}$ state as reference state $\left(\Delta G_{N}=0\right)$, the 402 free energy of the I and D states at each urea concentration can be expressed as $\Delta G_{I}\left(C_{\mathrm{Urea}}\right)=\Delta \mathrm{G}_{\mathrm{I}}^{0}+m_{I} \cdot C_{\mathrm{Urea}}$ and $403 \Delta G_{\mathrm{D}}\left(C_{\text {Urea }}\right)=\Delta \mathrm{G}_{\mathrm{D}}^{0}+m_{D} \cdot C_{\text {Urea }}$, respectively, where $\Delta \mathrm{G}_{\mathrm{I}}^{0}$ and $\Delta \mathrm{G}_{\mathrm{U}}^{0}$ are the free energy of the I and $\mathrm{D}$ state in 404 absence of urea, and $m_{I}$ and $m_{D}$ are the cooperativity of transition from the $\mathrm{N}$ state to I state, and from $\mathrm{N}$ state to 405 D state, respectively. For a cooperative two-state transition induced by a particular denaturant, the m-value is 406 proportional to the surface area exposed upon protein denaturation and is generally proportional to the protein 407 size. The linear relationship between m-values and globular protein chain lengths have been reported for 408 denaturant-induced protein unfolding (Ghosh \& Dill, 2009). Thus, the final fitting function for the 3-state 409 transition is as follows:

$$
\left.F I R\left(C_{\text {urea }}\right)=\frac{\left(b_{\mathrm{N}}+s_{\mathrm{N}} \cdot C_{\text {Urea }}\right)+\left(b_{\mathrm{I}}+s_{\mathrm{I}} \cdot C_{\text {Urea }}\right) \cdot \operatorname{Exp}\left(-\frac{\Delta G_{\mathrm{I}}^{0}+m_{\mathrm{I}} \cdot C_{\mathrm{Urea}}}{\mathrm{R} \cdot T}\right)+\left(b_{\mathrm{U}}+\mathrm{S}_{\mathrm{U}} \cdot C_{\text {Urea }}\right) \cdot \operatorname{Exp}\left(-\frac{\Delta G_{\mathrm{D}}^{0}+m_{\mathrm{D}} \cdot C_{\text {Urea }}}{\mathrm{R} \cdot T}\right)}{1+\operatorname{Exp}\left(-\frac{\Delta G_{\mathrm{I}}^{0}+m_{\mathrm{I}} \cdot C_{\text {Urea }}}{\mathrm{R} \cdot T}\right)+\operatorname{Exp}\left(-\frac{\Delta G_{\mathrm{D}}^{0}+m_{\mathrm{D}} \cdot C_{\text {Urea }}}{\mathrm{R} \cdot T}\right)} \text { (Equation } 1\right)
$$

412 constructs. The data were globally fit with shared $s_{\mathrm{N}}, s_{\mathrm{I}}, \mathrm{s}_{\mathrm{D}}, m_{\mathrm{I}}$ and $m_{\mathrm{D}}$, and individual $b_{\mathrm{N}}, b_{\mathrm{I}}, b_{\mathrm{D}}, \Delta G_{\mathrm{I}}^{0}$ and $\Delta G_{\mathrm{D}}^{0}$

413 for each construct. The rationale for fitting the baseline slope for each state to a shared value between the four constructs is that the $\mathrm{N}$ - and $\mathrm{C}$ - terminal linker does not contain any tryptophan. The rationale for the four 
A1-paper v17-eLife.docx

415 constructs to share the same m-values for the I state and D states is that the four constructs only differ in the O-

416 glycosylated linkers which are not folded.

417 For heat denaturation, A1 $(0.25$ to $0.5 \mathrm{mg} / \mathrm{mL})$ was in $20 \mathrm{mM}$ HEPES pH 7.5, $150 \mathrm{mM} \mathrm{NaCl}$. FIR was

418 measured in the Prometheus NT48 while temperature was ramped from 30 to $85^{\circ} \mathrm{C}$ at a rate of $1{ }^{\circ} \mathrm{C} / \mathrm{min}$ using an

419 excitation power of $50 \%$. Additionally, the intensity of backscattered light was recorded as a measure of

420 aggregation.

Hydrogen deuterium exchange mass spectrometry. Hydrogen deuterium exchange experiments were

422 essentially as reported previously (Iacob, 2013; Le et al., 2018). Comprehensive experimental details and

423 parameters are provided in Table 1, in the recommended (Masson et al., 2019) tabular format. All HDXMS data

424 have been deposited to the ProteomeXchange Consortium via the PRIDE (Perez-Riverol et al., 2019) partner

425 repository and the dataset identifier is pending. 
TABLE 1. HDX MS Data Summary and list of experimental parameters

\begin{tabular}{|c|c|c|c|c|}
\hline Data Set & A1-short & $\mathrm{A} 1 \mathrm{~N}$ & $\mathrm{~A} 1 \mathrm{C}$ & $\mathrm{A} 1 \mathrm{NC}$ \\
\hline HDX reaction details ${ }^{\mathrm{a}}$ & \multicolumn{4}{|c|}{$\begin{array}{c}\text { 15-fold dilution with labeling buffer at } 20^{\circ} \mathrm{C} \text {, final } \mathrm{D}_{2} \mathrm{O} \text { level }=93.3 \%, \mathrm{pH}_{\text {read }}=7.10 \text {; } \\
\text { equal volume quench buffer at } 0^{\circ} \mathrm{C}, \mathrm{pH}_{\text {read }}=2.5\end{array}$} \\
\hline HDX time course & \multicolumn{4}{|c|}{$10 \mathrm{~s}, 1 \mathrm{~m}, 10 \mathrm{~m}, 1 \mathrm{hr}, 4 \mathrm{hr}$} \\
\hline HDX controls & \multicolumn{4}{|c|}{3 undeuterated for each condition } \\
\hline Back-exchange & \multicolumn{4}{|c|}{$30-35 \%$} \\
\hline Number of peptides & 102 & 103 & 101 & 108 \\
\hline Sequence coverage & $93.2 \%$ & $92.5 \%$ & $91.8 \%$ & $90.9 \%$ \\
\hline $\begin{array}{l}\text { Avg. peptide length } \\
\text { (a.a.) }\end{array}$ & 12.3 & 12.2 & 12.3 & 12.3 \\
\hline Redundancy & 5.4 & 5.14 & 4.89 & 5.77 \\
\hline Replicates & \multicolumn{4}{|c|}{2 technical for each condition } \\
\hline $\begin{array}{l}\text { HDX } \\
\text { Repeatability }^{b}\end{array}$ & \multicolumn{4}{|c|}{$+/-0.15$ relative $\mathrm{Da}$} \\
\hline
\end{tabular}

a labeling buffer: $20 \mathrm{mM}$ HEPES, $150 \mathrm{mM} \mathrm{NaCl}, 99 \% \mathrm{D}_{2} \mathrm{O}$, pD 7.5;

quench buffer: $300 \mathrm{mM}$ sodium phosphate, $0.25 \mathrm{M}$ tris (2-carboxyethyl)phosphine hydrochloride (TCEP$\mathrm{HCl}), \mathrm{H}_{2} \mathrm{O}$ pH 2.5

${ }^{\mathrm{b}}$ All reported values are the average relative deuterium level as given by the DynamX software, which in some cases is an average of more than one charge state, across all peptides in both technical replicates. No statistical tests were applied to the HDX MS measurements

Briefly, A1 short and each O-glycosylated protein construct ( $28 \mu \mathrm{M}$ in $20 \mathrm{mM}$ HEPES, $150 \mathrm{mM} \mathrm{NaCl}$ )

was diluted 15-fold into $20 \mathrm{mM}$ HEPES, $150 \mathrm{mM} \mathrm{NaCl}, 99 \% \mathrm{D}_{2} \mathrm{O}(\mathrm{pD} 7.5)$ at room temperature. At deuterium

430 exchange time points from $10 \mathrm{~s}$ to $240 \mathrm{~min}$, an aliquot was quenched by adjusting the $\mathrm{pH}$ to 2.5 with an equal

431 volume of $300 \mathrm{mM}$ sodium phosphate, $0.25 \mathrm{M}$ tris (2-carboxyethyl)phosphine hydrochloride (TCEP-HCl), $\mathrm{H}_{2} \mathrm{O}$. 
A1-paper v17-eLife.docx

432 Samples were analyzed as previously described (Iacob, 2013; Wales, 2008). They were digested offline with 10

$433 \mathrm{mg} / \mathrm{mL}$ pepsin in water for $5 \mathrm{~min}$ on ice, then injected into a custom Waters nanoACQUITY UPLC HDX

434 Manager $^{\mathrm{TM}}$. All mass spectra were acquired using a Waters Synapt G2-Si HDMS ${ }^{\mathrm{E}}$ mass spectrometer.

435 Comparison experiments were done under identical experimental conditions such that deuterium levels were not

436 corrected for back-exchange and are therefore reported as relative (Wales \& Engen, 2006). All experiments were

437 performed in duplicate. The error of measuring the mass of each peptide was $\pm 0.15 \mathrm{Da}$ in this experimental setup.

438 The peptides were identified using PLGS 3.0.1 software and the HDX MS data were processed using DynamX

4393.0 (Waters Corp., USA). Peptides common to A1+OGly $+\mathrm{N}+\mathrm{C}$ and the shorter constructs were followed with

440 HDX, with an overall sequence coverage of $90.9 \%$. In total, 108 peptic peptides were followed with hydrogen

441 deuterium exchange uptake plots (Supplemental Figures 1-5). 
bioRxiv preprint doi: https://doi.org/10.1101/2022.01.13.476208; this version posted January 13, 2022. The copyright holder for this preprint (which was not certified by peer review) is the author/funder, who has granted bioRxiv a license to display the preprint in perpetuity. It is made available under aCC-BY 4.0 International license.

A1-paper v17-eLife.docx

\section{Supplementary Materials.}

Figure 5 - Figure Supplement 1. Complete HDX peptide coverage at each indicated time point. (A-

B) Peptides from the indicated A1 fragments are colored according to the key with deuterium exchange at all timepoints as \% of the available amide backbone $\mathrm{H}$ atoms in each peptide. Residue number based on the immature sequence indicated above and secondary structures indicated below.

Figure 5 - Figure Supplement 2. Complete HDX peptide coverage at each indicated time point. (AB) Peptides from the indicated A1 fragments are colored according to the key with deuterium exchange at all timepoints as $\%$ of the available amide backbone $\mathrm{H}$ atoms in each peptide. Residue number based on the immature sequence indicated above and secondary structures indicated below.

Figure 5 - Figure Supplement 3. Full HDX kinetics for peptides, one of three figures.

Figure 5 - Figure Supplement 4. Full HDX kinetics for peptides, two of three figures.

Figure 5 - Figure Supplement 5. Full HDX kinetics for peptides, three of three figures.

Source Data Files.

Figure 4D - Source Data 1. A1 Short.

Figure 4D - Source Data 2. A1 Short+ C.

Figure 4D -Source Data 3. A1 Short+N.

Figure 4D - Source Data 4. A1 Short+NC. 
bioRxiv preprint doi: https://doi.org/10.1101/2022.01.13.476208; this version posted January $13,2022$. The copyright holder for this preprint

(which was not certified by peer review) is the author/funder, who has granted bioRxiv a license to display the preprint in perpetuity. It is made available under aCC-BY 4.0 International license.

A1-paper v17-eLife.docx

\section{References}

Aponte-Santamaria, C., Huck, V., Posch, S., Bronowska, A. K., Grassle, S., Brehm, M. A., Obser, T., Schneppenheim, R., Hinterdorfer, P., Schneider, S. W., Baldauf, C., \& Grater, F. (2015, May 05). Forcesensitive autoinhibition of the von Willebrand factor is mediated by interdomain interactions. Biophys $J$, 108(9), 2312-2321. https://doi.org/10.1016/j.bpj.2015.03.041

Arce, N. A., Cao, W., Brown, A. K., Legan, E. R., Wilson, M. S., Xu, E. R., Berndt, M. C., Emsley, J., Zhang, X. F., \& Li, R. (2021, Apr 21). Activation of von Willebrand factor via mechanical unfolding of its discontinuous autoinhibitory module. Nat Commun, 12(1), 2360. https://doi.org/10.1038/s41467-021$\underline{22634-x}$

Auton, M., Cruz, M. A., \& Moake, J. (2007, Feb 23). Conformational stability and domain unfolding of the Von Willebrand factor A domains. J Mol Biol, 366(3), 986-1000. http://www.ncbi.nlm.nih.gov/entrez/query.fcgi?cmd=Retrieve $\& \mathrm{db}=\mathrm{PubMed} \& \mathrm{dopt}=$ Citation\&list uids=1 $\underline{7187823}$

Auton, M., Sedlak, E., Marek, J., Wu, T., Zhu, C., \& Cruz, M. A. (2009). Changes in thermodynamic stability of von Willebrand factor differentially affect the force-dependent binding to platelet GPIbalpha. Biophys $J$, 97(2), 618-627. https://doi.org/S0006-3495(09)00967-9 [pii]

10.1016/j.bpj.2009.05.009

Auton, M., Sowa, K. E., Behymer, M., \& Cruz, M. A. (2012, Apr 27). N-terminal flanking region of A1 domain in von Willebrand factor stabilizes structure of A1A2A3 complex and modulates platelet activation under shear stress [Clinical Trial

Research Support, N.I.H., Extramural

Research Support, Non-U.S. Gov't]. J Biol Chem, 287(18), 14579-14585. https://doi.org/10.1074/jbc.M112.348573

Auton, M., Sowa, K. E., Smith, S. M., Sedlak, E., Vijayan, K. V., \& Cruz, M. A. (2010, Jul 23). Destabilization of the A1 domain in von Willebrand factor dissociates the A1A2A3 tri-domain and provokes spontaneous binding to glycoprotein Ib $\alpha$ and platelet activation under shear stress. J Biol Chem, 285(30), 2283122839. https://doi.org/10.1074/jbc.M110.103358

Auton, M., Zhu, C., \& Cruz, M. A. (2010, Aug 9). The mechanism of VWF-mediated platelet GPIba binding. Biophys J, 99(4), 1192-1201. https://doi.org/S0006-3495(10)00708-3 [pii]

10.1016/j.bpj.2010.06.002

Blenner, M. A., Dong, X., \& Springer, T. A. (2014, Feb 28). Structural basis of regulation of von Willebrand factor binding to glycoprotein Ib. J Biol Chem, 289(9), 5565-5579. https://doi.org/10.1074/jbc.M113.511220

Bonazza, K., Rottensteiner, H., Schrenk, G., Frank, J., Allmaier, G., Turecek, P. L., Scheiflinger, F., \& Friedbacher, G. (2015, Oct. 20). Shear-dependent interactions of von Willebrand Factor with factor viii and protease ADAMTS 13 demonstrated at a single molecule level by atomic force microscopy. Anal Chem., 87(20), 10299-10305. https://doi.org/10.1021/acs.analchem.5b02078

Clemetson, K. J. (1983). Platelet membrane glycoprotein I: Structure and function. The domain of glycoprotein I involved in the von Willebrand receptor. Blood Cells, 9, 319-329.

http://www.ncbi.nlm.nih.gov/entrez/query.fcgi? $\mathrm{cmd}=$ Retrieve $\& \mathrm{db}=\mathrm{PubMed} \& \mathrm{dopt}=\mathrm{Citation} \&$ list uids $=6$ $\underline{229300}$ 
bioRxiv preprint doi: https://doi.org/10.1101/2022.01.13.476208; this version posted January 13,2022 . The copyright holder for this preprint

(which was not certified by peer review) is the author/funder, who has granted bioRxiv a license to display the preprint in perpetuity. It is made available under aCC-BY 4.0 International license.

A1-paper v17-eLife.docx

Deng, W., Voos, K. M., Colucci, J. K., Legan, E. R., Ortlund, E. A., Lollar, P., \& Li, R. (2018, Oct). Delimiting the autoinhibitory module of von Willebrand factor. J Thromb Haemost, 16(10), 2097-2105. https://doi.org/10.1111/jth.14251

Deng, W., Wang, Y., Druzak, S. A., Healey, J. F., Syed, A. K., Lollar, P., \& Li, R. (2017, Sep). A discontinuous autoinhibitory module masks the A1 domain of von Willebrand factor. $J$ Thromb Haemost, 15(9), 18671877. https://doi.org/10.1111/jth.13775

Dumas, J. J., Kumar, R., McDonagh, T., Sullivan, F., Stahl, M. L., Somers, W. S., \& Mosyak, L. (2004, May 28). Crystal structure of the wild-type von Willebrand factor A1-glycoprotein Ib $\alpha$ complex reveals conformation differences with a complex bearing von Willebrand disease mutations. J. Biol. Chem., 279, 23327-23334. http://www.ncbi.nlm.nih.gov/entrez/query.fcgi?cmd=Retrieve \&db=PubMed\&dopt=Citation\&list uids=1 $\underline{5039442}$

Fu, H., Jiang, Y., Yang, D., Scheiflinger, F., Wong, W. P., \& Springer, T. A. (2017, Aug 23). Flow-induced elongation of von Willebrand factor precedes tension-dependent activation. Nat Commun, 8(1), 324. https://doi.org/10.1038/s41467-017-00230-2

Ghosh, K., \& Dill, K. A. (2009, Jun 30). Computing protein stabilities from their chain lengths. Proc Natl Acad Sci U S A, 106(26), 10649-10654. https://doi.org/10.1073/pnas.0903995106

Huizinga, E. G., Tsuji, S., Romijn, R. A., Schiphorst, M. E., de Groot, P. G., Sixma, J. J., \& Gros, P. (2002). Structures of glycoprotein Ib $\alpha$ and its complex with von Willebrand factor A1 domain. Science, 297, 1176-1179. http://www.ncbi.nlm.nih.gov/htbinpost/Entrez/query? $\mathrm{db}=\mathrm{m} \&$ form $=6 \& \mathrm{dopt}=\mathrm{r} \&$ uid $=12183630$

Iacob, R. E. B.-A., G. M.; Makowski, L.; Engen, J. R.; Berkowitz, S. A.; Houde, D. (2013, Dec). Investigating monoclonal antibody aggregation using a combination of H/DX-MS and other biophysical measurements. J Pharm Sci, 102(12), 4315-4329. https://doi.org/10.1002/jps.23754

Interlandi, G., Yakovenko, O., Tu, A. Y., Harris, J., Le, J., Chen, J., López, J. A., \& Thomas, W. E. (2017, Nov 10). Specific electrostatic interactions between charged amino acid residues regulate binding of von Willebrand factor to blood platelets. J Biol Chem., 292(45), 18608-18617. https://doi.org/10.1074/jbc.M117.797456

Ju, L., Dong, J. F., Cruz, M. A., \& Zhu, C. (2013, Nov 8). The N-terminal flanking region of the A1 domain

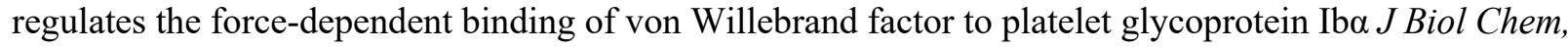
288(45), 32289-32301. https://doi.org/10.1074/jbc.M113.504001

Kim, J., Hudson, N. E., \& Springer, T. A. (2015, Apr 14). Force-induced on-rate switching and modulation by mutations in gain-of-function von Willebrand diseases. Proc Natl Acad Sci U S A, 112(15), 4648-4653. https://doi.org/10.1073/pnas.1501689112

Kim, J., Zhang, C. Z., Zhang, X., \& Springer, T. A. (2010, Aug 19). A mechanically stabilized receptor-ligand flex-bond important in the vasculature. Nature, 466(7309), 992-995. https://doi.org/10.1038/nature09295

LaVallie, E. R., DiBlasio, E. A., Kovacic, S., Grant, K. L., Schendel, P. F., \& McCoy, J. M. (1993, Feb). A thioredoxin gene fusion expression system that circumvents inclusion body formation in the E. coli cytoplasm. Biotechnology (N Y), 11(2), 187-193. http://www.ncbi.nlm.nih.gov/pubmed/7763371 
bioRxiv preprint doi: https://doi.org/10.1101/2022.01.13.476208; this version posted January 13,2022 . The copyright holder for this preprint (which was not certified by peer review) is the author/funder, who has granted bioRxiv a license to display the preprint in perpetuity. It is made available under aCC-BY 4.0 International license.

A1-paper v17-eLife.docx

Le, V. Q., Iacob, R. E., Tian, Y., McConaughy, W., Jackson, J., Su, Y., Zhao, B., Engen, J. R., Pirruccello-Straub, M., \& Springer, T. A. (2018, Feb 1). Tolloid cleavage activates latent GDF8 by priming the pro-complex for dissociation. EMBO J, 37(3), 384-397. https://doi.org/10.15252/embj.201797931

Lobstein, J., Emrich, C. A., Jeans, C., Faulkner, M., Riggs, P., \& Berkmen, M. (2012). SHuffle, a novel Escherichia coli protein expression strain capable of correctly folding disulfide bonded proteins in its cytoplasm. Microb Cell Fact, 11, 56. https://doi.org/10.1186/1475-2859-11-56

Masson, G. R., Burke, J. E., Ahn, N. G., Anand, G. S., Borchers, C., Brier, S., Bou-Assaf, G. M., Engen, J. R., Englander, S. W., Faber, J., Garlish, R., Griffin, P. R., Gross, M. L., Guttman, M., Hamuro, Y., Heck, A. J. R., Houde, D., Iacob, R. E., Jorgensen, T. J. D., Kaltashov, I. A., Klinman, J. P., Konermann, L., Man, P., Mayne, L., Pascal, B. D., Reichmann, D., Skehel, M., Snijder, J., Strutzenberg, T. S., Underbakke, E. S., Wagner, C., Wales, T. E., Walters, B. T., Weis, D. D., Wilson, D. J., Wintrode, P. L., Zhang, Z., Zheng, J., Schriemer, D. C., \& Rand, K. D. (2019, Jul). Recommendations for performing, interpreting and reporting hydrogen deuterium exchange mass spectrometry (HDX-MS) experiments. Nat Methods, 16(7), 595-602. https://doi.org/10.1038/s41592-019-0459-y

Miyata, S., \& Ruggeri, Z. M. (1999, Mar 5). Distinct structural attributes regulating von Willebrand factor A1 domain interaction with platelet glycoprotein Ibalpha under flow. J Biol Chem, 274(10), 6586-6593. https://www.ncbi.nlm.nih.gov/pubmed/10037753

Motlagh, H. N., Wrabl, J. O., Li, J., \& Hilser, V. J. (2014, Apr 17). The ensemble nature of allostery. Nature, 508(7496), 331-339. https://doi.org/10.1038/nature13001

Nakayama, T., Matsushita, T., Dong, Z., Sadler, J. E., Jorieux, S., Mazurier, C., Meyer, D., Kojima, T., \& Saito, H. (2002, Jun 14). Identification of the regulatory elements of the human von Willebrand factor for binding to platelet GPIb. Importance of structural integrity of the regions flanked by the CYS1272CYS1458 disulfide bond. J. Biol. Chem., 277, 22063-22072. http://www.ncbi.nlm.nih.gov/entrez/query.fcgi?cmd=Retrieve \&db=PubMed\&dopt=Citation\&list_uids=1 $\underline{1943773}$

Parker, E. T., \& Lollar, P. (2021, Jan-Jun). Conformation of the von Willebrand factor/factor VIII complex in quasi-static flow. J Biol Chem, 296, 100420. https://doi.org/10.1016/j.jbc.2021.100420

Perez-Riverol, Y., Csordas, A., Bai, J., Bernal-Llinares, M., Hewapathirana, S., Kundu, D. J., Inuganti, A., Griss, J., Mayer, G., Eisenacher, M., Perez, E., Uszkoreit, J., Pfeuffer, J., Sachsenberg, T., Yilmaz, S., Tiwary, S., Cox, J., Audain, E., Walzer, M., Jarnuczak, A. F., Ternent, T., Brazma, A., \& Vizcaino, J. A. (2019, Jan 8). The PRIDE database and related tools and resources in 2019: improving support for quantification data. Nucleic Acids Res, 47(D1), D442-D450. https://doi.org/10.1093/nar/gky1106

Richards, F. M. (1977). Areas, volumes, packing, and protein structure. Annual Review of Bioengineering, 6, 151176.

Santoro, M. M., \& Bolen, D. W. (1988, Oct 18). Unfolding free energy changes determined by the linear extrapolation method. 1. Unfolding of phenylmethanesulfonyl alpha-chymotrypsin using different denaturants. Biochemistry, 27(21), 8063-8068. https://www.ncbi.nlm.nih.gov/pubmed/3233195

Solecka, B. A., Weise, C., Laffan, M. A., \& Kannicht, C. (2016, Apr). Site-specific analysis of von Willebrand factor O-glycosylation. J Thromb Haemost, 14(4), 733-746. https://doi.org/10.1111/jth.13260 
bioRxiv preprint doi: https://doi.org/10.1101/2022.01.13.476208; this version posted January $13,2022$. The copyright holder for this preprint

(which was not certified by peer review) is the author/funder, who has granted bioRxiv a license to display the preprint in perpetuity. It is made available under aCC-BY 4.0 International license.

A1-paper v17-eLife.docx

612

613

614

615

616

617

618

619

620

621

622

623

624

625

626

627

628

629

630

631

632

633

634

635

636

637

638

639

640

641

642

643

644

645

646

647

648

649

650

651

652

653

654

655

656

657

658

659

660

661

662

Springer, T. A. (2014, Aug 28). von Willebrand factor, Jedi knight of the bloodstream [Review]. Blood, 124(9), 1412-1425. https://doi.org/10.1182/blood-2014-05-378638

Sugimoto, M., Dent, J., McClintock, R., Ware, J., \& Ruggeri, Z. M. (1993, Jun 5). Analysis of structure-function relationships in the platelet membrane glycoprotein Ib-binding domain of von Willebrand's factor by expression of deletion mutants. J Biol Chem, 268(16), 12185-12192.

https://www.ncbi.nlm.nih.gov/pubmed/8505338

Tischer, A., Machha, V. R., Frontroth, J. P., Brehm, M. A., Obser, T., Schneppenheim, R., Mayne, L., Walter Englander, S., \& Auton, M. (2017, Jul 07). Enhanced Local Disorder in a Clinically Elusive von Willebrand Factor Provokes High-Affinity Platelet Clumping. J Mol Biol, 429(14), 2161-2177. https://doi.org/10.1016/j.jmb.2017.05.013

Tischer, A., Machha, V. R., Moon-Tasson, L., Benson, L. M., \& Auton, M. (2020, Jan). Glycosylation sterically inhibits platelet adhesion to von Willebrand factor without altering intrinsic conformational dynamics. $J$ Thromb Haemost, 18(1), 79-90. https://doi.org/10.1111/jth.14628

Tischer, A., Madde, P., Blancas-Mejia, L. M., \& Auton, M. (2014, May). A molten globule intermediate of the von Willebrand factor A1 domain firmly tethers platelets under shear flow. Proteins, 82(5), 867-878. https://doi.org/10.1002/prot.24464

Titani, K., Kumar, S., Takio, K., Ericsson, L. H., Wade, R. D., Ashida, K., Walsh, K. A., Chopek, M. W., Sadler, J. E., \& Fujikawa, K. (1986, Jun 3). Amino acid sequence of human von Willebrand factor. Biochemistry, 25(11), 3171-3184.

http://www.ncbi.nlm.nih.gov/entrez/query.fcgi?cmd=Retrieve \&db=PubMed\&dopt=Citation\&list_uids=3 $\underline{524673}$

Ulrichts, H., Udvardy, M., Lenting, P. J., Pareyn, I., Vandeputte, N., Vanhoorelbeke, K., \& Deckmyn, H. (2006, Feb 24). Shielding of the A1 domain by the D'D3 domains of von Willebrand factor modulates its interaction with platelet glycoprotein Ib-IX-V. J Biol Chem, 281(8), 4699-4707. http://www.ncbi.nlm.nih.gov/entrez/query.fcgi? $\mathrm{cmd}=$ Retrieve $\& \mathrm{db}=$ PubMed\&dopt=Citation\&list_uids=1 $\underline{6373331}$

Wales, T. E., \& Engen, J. R. (2006, Jan-Feb). Hydrogen exchange mass spectrometry for the analysis of protein dynamics. Mass Spectrometry Reviews, 25(1), 158-170. https://doi.org/10.1002/mas.20064

Wales, T. E. F., K. E.; Gerhardt, G. C.; Engen, J. R. (2008, Sep 1). High-speed and high-resolution UPLC separation at zero degrees Celsius. Anal Chem, 80(17), 6815-6820. https://doi.org/10.1021/ac8008862

Woollett, G. R., Williams, A. F., \& Shotton, D. M. (1985). Visualisation by low-angle shadowing of the leucocyte-common antigen: A major cell surface glycoprotein of lymphocytes. EMBO J., 4, 2827-2830. http://www.ncbi.nlm.nih.gov/entrez/query.fcgi? $\mathrm{cmd}=$ Retrieve $\& \mathrm{db}=\mathrm{PubMed} \& \mathrm{dopt}=$ Citation\&list uids=2 $\underline{933249}$

Xu, A. J., \& Springer, T. A. (2013, Mar 1). Mechanisms by which von Willebrand disease mutations destabilize the A2 domain. J Biol Chem, 288(9), 6317-6324. https://doi.org/10.1074/jbc.M112.422618

Zhang, X., Halvorsen, K., Zhang, C. Z., Wong, W. P., \& Springer, T. A. (2009, Jun 5). Mechanoenzymatic cleavage of the ultralarge vascular protein von Willebrand factor. Science, 324(5932), 1330-1334. https://doi.org/10.1126/science.1170905 
Zhou, Y. F., Eng, E. T., Nishida, N., Lu, C., Walz, T., \& Springer, T. A. (2011, Aug 19). A pH-regulated dimeric bouquet in the structure of von Willebrand factor. EMBO J, 30(19), 4098-4111. https://oi.org/10.1038/emboj.2011.297

Zhou, Y. F., \& Springer, T. A. (2014, Mar 20). Highly reinforced structure of a C-terminal dimerization domain in von Willebrand factor. Blood, 123(12), 1785-1793. https://doi.org/10.1182/blood-2013-11-523639

Acknowledgements. We would like to thank Prof. Thomas Wales for helpful discussions and a research collaboration with the Waters Corporation (JRE). We thank Yang Su for writing and using code to display HDXMS data for figure preparation. We acknowledge support from the National Hemophilia Foundation and from the Austrian Science Fund (FWF), Erwin Schrödinger Fellowship number J4081-B21, NIH grant F32HL126386, and NIH grant R01-HL148755.

Author Contributions. Investigation: KB, REI, and NEH. Formal analysis: KB, REI, JRE, and JL. Conceptualization: TAS. Methodology: TAS, JRE, and CL. Writing- Original Draft: KB and TAS. WritingReview and Editing: TAS, JRE, CL, KB, and JL. Supervision: JRE and TAS. Funding acquisition: TAS, KB, NEH, and JRE.

Data and materials availability statement. All data are contained within the manuscript. All HDXMS datafile have been deposited to the ProteomeXchange Consortium via the PRIDE (Perez-Riverol et al., 2019) partner repository and the dataset identifier is pending.

Conflict of Interest Disclosures. The authors declare that they have no conflict of interest with the contents of this article. 
bioRxiv preprint doi: https://doi.org/10.1101/2022.01.13.476208; this version posted January 13, 2022. The copyright holder for this preprint (which was not certified by peer review) is the author/funder, who has granted bioRxiv a license to display the preprint in perpetuity. It is made available under aCC-BY 4.0 International license.

A. A1short 1300 1350 1400 1450

$10 \mathrm{~s} 5$

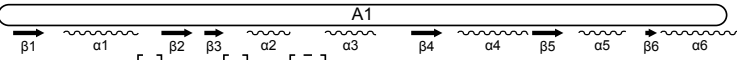

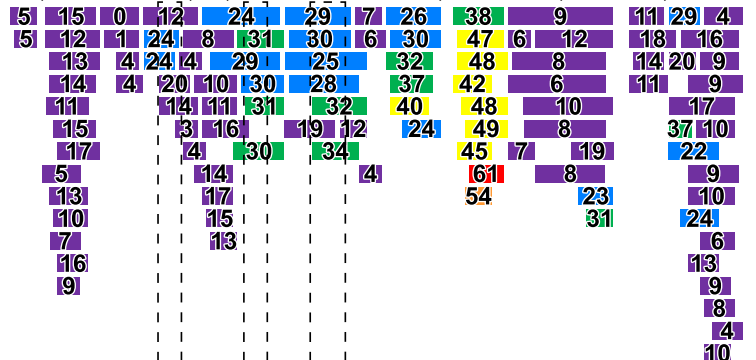

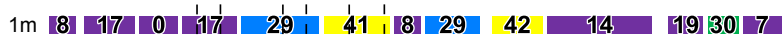
[6] $\begin{array}{lllllllllllllll}13 & 1 & 31 & 9 & 140 & 42 & \text { I } & 3 & 31 & 51 & 13 & 16 & 24 & 23\end{array}$

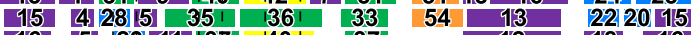

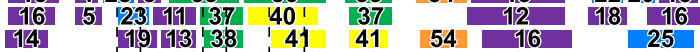

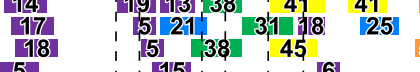
16 । 15151 (6.
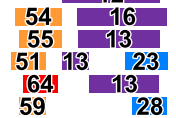
25
3919 3919
29 12. 11161 8
$19]$
111 14!

\begin{tabular}{ll|}
1 & 144 \\
1 & 1
\end{tabular}

$\begin{array}{llll}1 & 1 & 1 & 1 \\ 1 & 1 & 1 & 1\end{array}$

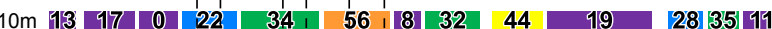

$\begin{array}{lllllllllllll}9 & 14 & 0 & 39 & 9 & 145 & 58 & 7 & 34 & 52 & 22 & 21 & 30\end{array}$

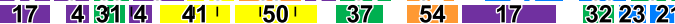

$\begin{array}{lllllllllll}177 & 5 & 32 & 15 & 40 & 55 & 39 & 46 & 17 & 27 & 26\end{array}$

$\begin{array}{lllllllll}16 & 25 & 15 & 42 & 50 & 42 & 54 & 19 & 34\end{array}$

$21 \quad 14126+4425 \quad 30 \quad 5520 \quad 4229$

$\begin{array}{lllllllll}7 & 1 & 51 & 45 & 57 & 52 & 20 & 27 & 41 \\ 7 & 1 & 1151 & 1 & 1 & 171 & {[66]} & 16 & 28\end{array}$

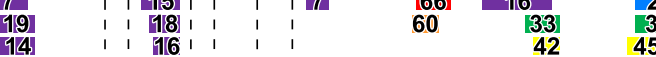

$\begin{array}{llllllll}110] & 1 & 1 & 19 . & 1 & 1 & 1 & 45 \\ 22 & 1 & 1 & 1 & 1 & 1 & 1 & 19\end{array}$

14:

24

6

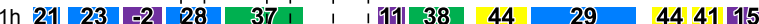

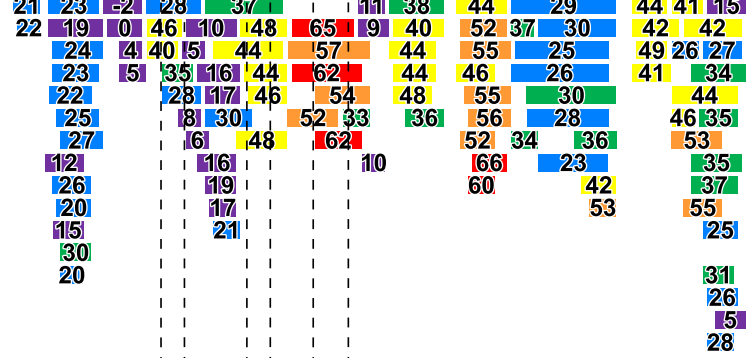

28

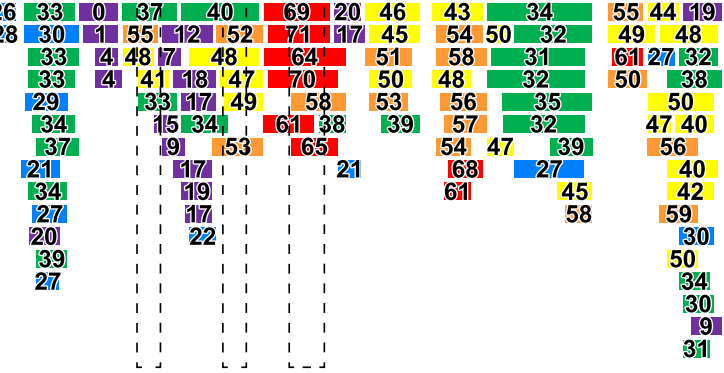

B. $A 1+$ Ogly $+\mathrm{N}$

1250

1300

Residue Number

1350

1400

1450

10s 33

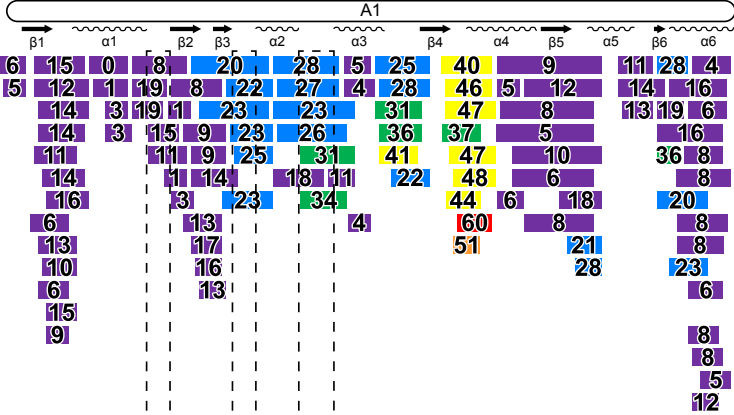

$1 \mathrm{~m} \quad 50$

\begin{tabular}{llllllllll}
8 & 17 & 1 & 10 & 26 & 39 & 6 & 27 \\
\hline 6 & 13 & 0 & 21 & 8 & 30 & 41 & 5
\end{tabular}

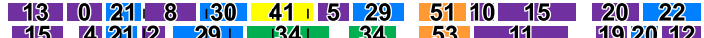

$\begin{array}{llllllll}15 & 4121122 & 29 I & 1341 & 34 & 53 & 11 & \text { 119]20 112 }\end{array}$

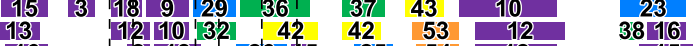

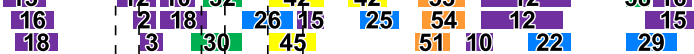

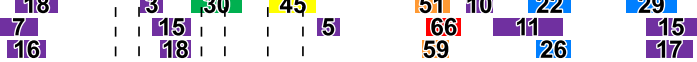

$\begin{array}{lllllllllll}146 & 16 & 118] & 1 & 1 & 1 & 59 & 26 & 17 \\ 1313 & 1 & 1 & 16 & 1 & 1 & 1 & 59 & 34 & 31\end{array}$

$\begin{array}{llll:llll}81 & 1 & 1 & 144 & 1 & 1 & 1 & 14 \\ 19] & 1 & 1 & 1 & 1 & 1 & 1 & 22 \\ 111 & 1 & 1 & 1 & 1 & 1 & 1 & \end{array}$

14

12
4
115

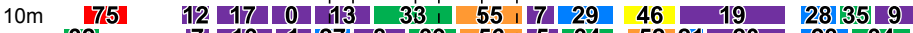

$\begin{array}{llllllllllllllll}17 & 13 & 1 & 27 & 8 & 139 & 56 & 1 & 5 & 34 & 52 & 21 & 20 & 28 & 34\end{array}$

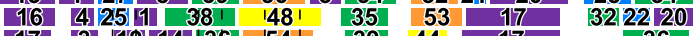

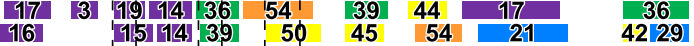

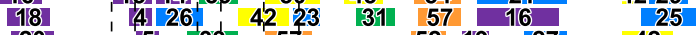

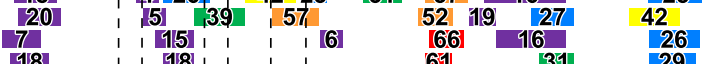

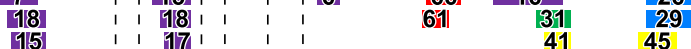

$\begin{array}{llll:llll}110] & 1 & 1 & 19 & 1 & 1 & 1 & 45 \\ 22 & 1 & 1 & 18\end{array}$

13

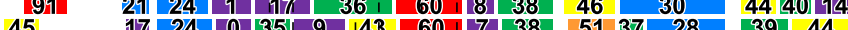

$\begin{array}{lllllll}22 & 40 & 53 & 25 & 492525\end{array}$

$\begin{array}{lllllll}23 & 45 & 26 & 45 & 45\end{array}$

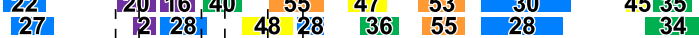

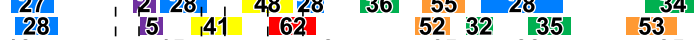

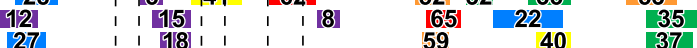

$\begin{array}{lllllllllll}27 & 1 & 1 & 18 & 1 & 1 & 1 & 59 & 40 & 37 \\ 22 & 1 & 1 & 17 & 1 & 1 & 1 & & 52 & 54\end{array}$

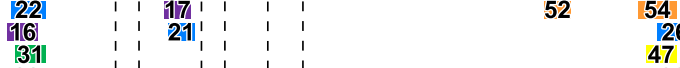

22

47
$30]$
26

26
29
29

4h $\quad$ 11000]

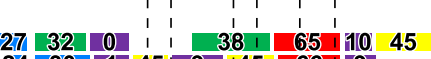

$\begin{array}{lllllllll}24 & 30 & 1 & 45 & 9 & 145 & 66 & 9\end{array}$

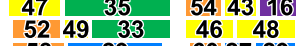

$\begin{array}{llllllll}32 & 39 & 43 & 59 & 48 & 58 & 29 & 60 \\ 27 / 29\end{array}$

$\begin{array}{llllllllll}32 & 3 & 34 & 16 & 40 & 65 & 48 & 47 & 30 & 49\end{array}$

$\begin{array}{lllllllll}30 & 24 & 177 & 42 & 55 & 52 & 55 & 34 & 4639 \\ 34 & 3 & 31 & 54 & 31 & 37 & 57 & 33 & 38\end{array}$

$\begin{array}{llllllllll}36 & 14 & 31 & 1 & 54 & 31 & 37 & 57 & 33 & \\ 36 & 14 & 46 & 164 & & 53 & 45 & 38 & 56\end{array}$

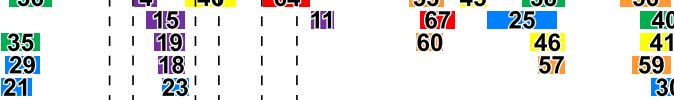

39
40
41
30
33
30
8

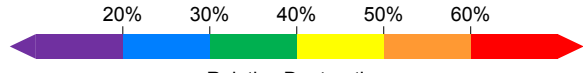

Relative Deuteration

Figure 5 - Figure Supplement 1. Complete HDX peptide coverage at each indicated time point. (A-B) Peptides from the indicated $\mathrm{A} 1$ fragments are colored according to the key with deuterium exchange at all timepoints as $\%$ of the available amide backbone $\mathrm{H}$ atoms in each peptide. Residue number based on the immature sequence indicated above and secondary structures indicated below. 
bioRxiv preprint doi: https://doi.org/10.1101/2022.01.13.476208; this version posted January 13, 2022. The copyright holder for this preprint (which was not certified by peer review) is the author/funder, who has granted bioRxiv a license to display the preprint in perpetuity. It is made available under aCC-BY 4.0 International license.

A. $A 1+$ Ogly+C 1300

Residue Number

1400

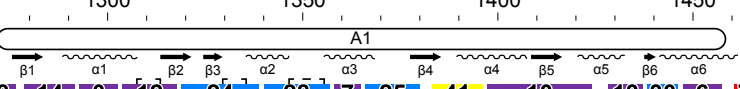

10s 8

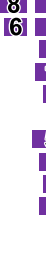

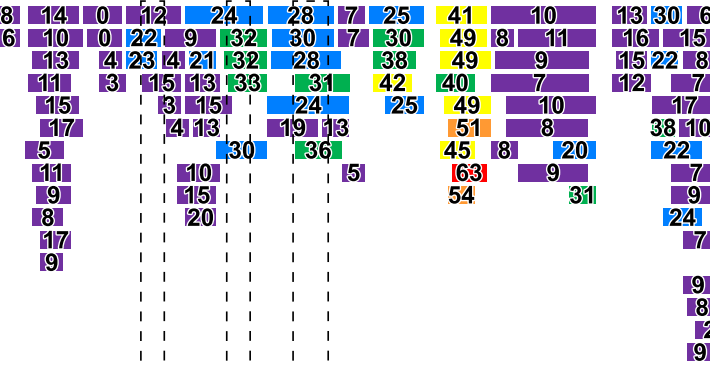

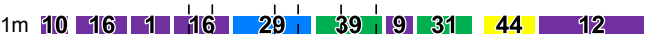

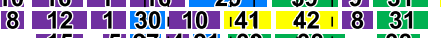

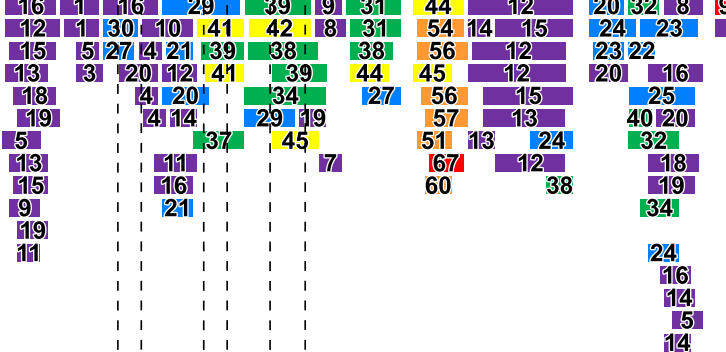

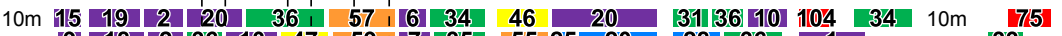

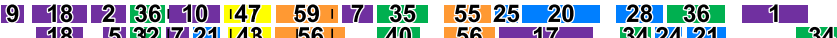

$\begin{array}{llllllll}118 & 15132171211 & 143 & 561 & 40 & 56 & 17 & 34242121\end{array}$

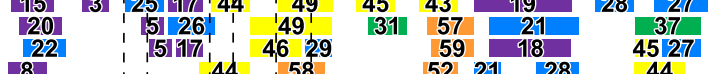

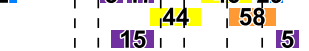

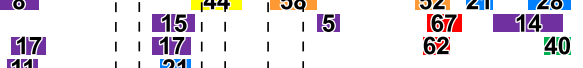

1111
115
115

(1)

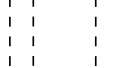

$\begin{array}{lllllll} & 1 & & 1 & 1 & 1 & 1 \\ 1 & 1 & & 1 & 1 & 1 \\ 1 & 1 & & 1 & 1 & 1\end{array}$

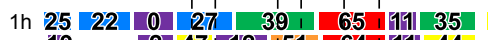

\section{9}

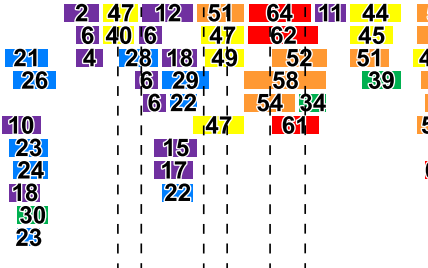

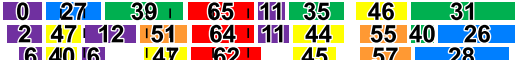

110

$\frac{128}{118}$
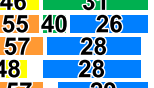

$\begin{array}{lll}57 & 29 \\ 57 & 27 \\ 52 & 38 & 37\end{array}$

$52.38 \quad 227$

63.

4512
44
28
30

28
30

37
121

1381

244
120
13
13

22

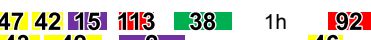

$\begin{array}{lll}43 & 42 & 2\end{array}$

542628

42

4455

54
36

36
35
58

58

49

32
26
28
28

4h $29 \begin{array}{llllllll}29 & -1 & 1 & 1 & 1 & 1 & 1 & 1 \\ & 41 & & 69 & 1 & 21\end{array}$

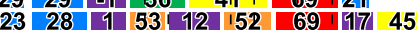

\begin{tabular}{ll|l|llllllll}
29 & 1 & 36 & $4 \pi$ & 1 & 69 & 121 & & 46 & 35 \\
28 & 1 & $53 !$ & 12 & 152 & 69 & 17 & 45 & 54 & 51 & 31 \\
30 & 6 & 47 & 19 & 22 & 147 & 68 & 49 & 57 & 31 \\
\hline
\end{tabular}

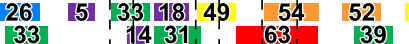

$\begin{array}{llllll}33 & 1431 & 63 \\ 19 & 1 & 19120, & 5937\end{array}$

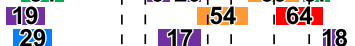

1291

$\begin{array}{llc:c:cc}1 & 1 & 177 & 1 & 1 & 1 \\ 1 & 1 & 17 & 1 & 1 & 1\end{array}$

\begin{tabular}{llll}
1 & 177 & 1 \\
1 & $21 \mid$ & 1 \\
\hline & 1 & 1
\end{tabular}

38:

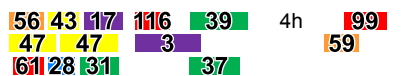

[61] 2831

$50 \quad 36$
-50

$\begin{array}{lrr}56 & 33 & 50 \\ 56 & 30 & 4739\end{array}$

$52 \quad 46 \quad 39$

$\begin{array}{ll}52 & 46 \\ 61 & 25 \\ & \end{array}$

54

54

40
58

58
31
50

34]

31
51

B. $\mathrm{A} 1+\mathrm{Og} l \mathrm{y}+\mathrm{N}+\mathrm{C}$

1250

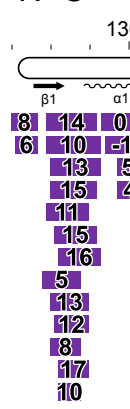

1300

Residue Number

$1350 \quad 1400$

$1400 \quad 1450$

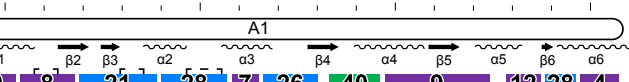

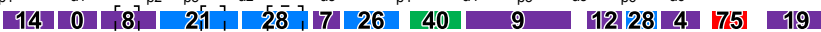
\begin{tabular}{lllllllllllllll}
10 & -1 & 20 & 8 & 25 & 29 & 5 & 28 & 48 & 71 & 13 & 16 & 15 & 3 & \\
\hline 13 & 5 & 19 & 13 & 22 & 251 & 29 & 48 & 7 & 14422 & 7 & & 20
\end{tabular}

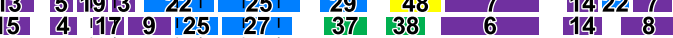

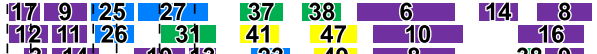

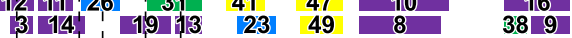

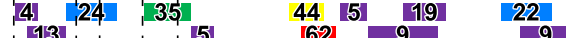

$\begin{array}{llllll}1 & 133 & 1 & 1 & 1 & 151\end{array}$

1,171

1 12 1

9
9

24

13)

(9)

(9)

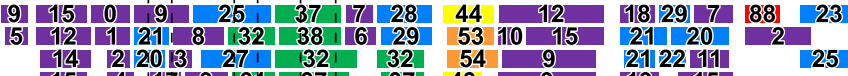

51525

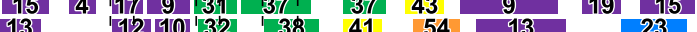

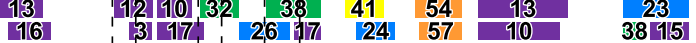

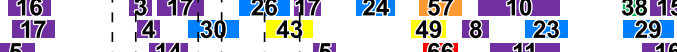

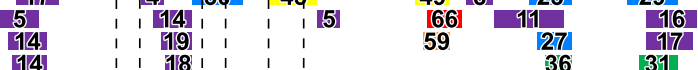

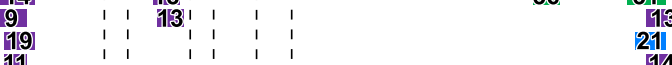

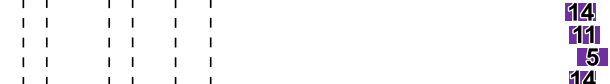

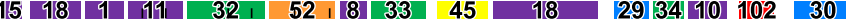
\begin{tabular}{llllllllllllllll}
8 & 15 & 1 & 26 & 9 & 140 & 55 & 1 & 7 & 34 & 53 & 21 & 20 & 29 & 35 & 2 \\
\hline
\end{tabular}

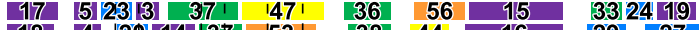

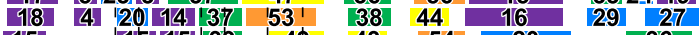

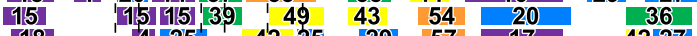

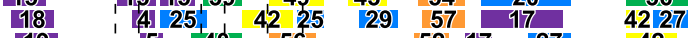

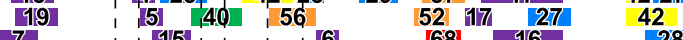

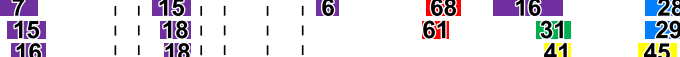

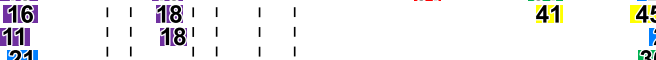

21
14

20

22

5

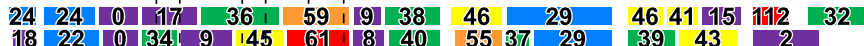

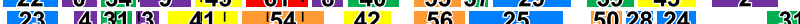

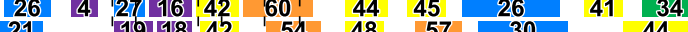

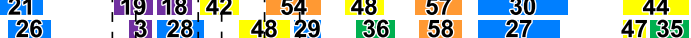

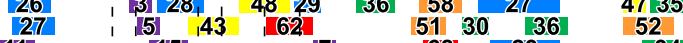

$\begin{array}{lllllllllll}11 & 1 & 1515 & 1 & 1 & 1 & 71 & 68 & 23 & 34 \\ 124 & 1 & 1 & 19] & 1 & 1 & 1 & 62 & 41 & 37\end{array}$

$\begin{array}{llllllllll}24 & 1 & 19 & 19 & 1 & 1 & 1 & 62 & 41 & 37 \\ 23 & 1 & 1 & 199 & 1 & 1 & 1 & & 54 & 55\end{array}$

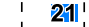

21

46

31

26

$\begin{array}{lllllllllllllll}29 & 33 & 1 & 24 & 38 & 63 & 11 & 44 & 45 & 33 & 57 & 43 & 181 & 1115 & 34\end{array}$

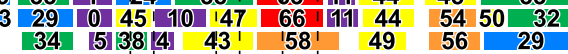

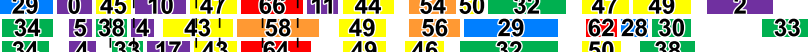

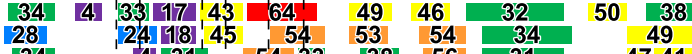

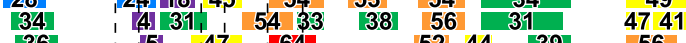

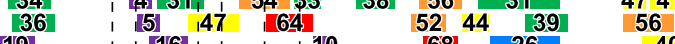

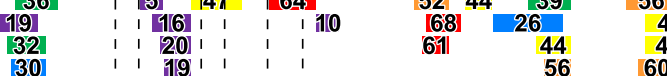

211

28
40
41
60
31
51
34
30
7
31

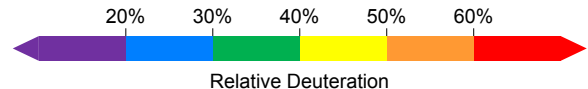

Figure 5 - Figure Supplement 2. Complete HDX peptide coverage at each indicated time point. (A-B) Peptides from the indicated $A 1$ fragments are colored according to the key with deuterium exchange at all timepoints as \% of the available amide backbone $\mathrm{H}$ atoms in each peptide. Residue number based on the immature sequence indicated above and secondary structures indicated below. 
bioRxiv preprint doi: https://doi.org/10.1101/2022.01.13.476208; this version posted January 13,2022 . The copyright holder for this preprint (which was not certified by peer review) is the author/funder, who has granted bioRxiv a license to display the preprint in perpetuity. It is made available under aCC-BY 4.0 International license. $X \mathrm{~A} 1+\mathrm{OGly}+\mathrm{N}+\mathrm{C} \diamond \mathrm{A} 1+\mathrm{OGly}+\mathrm{N} \bigcirc \mathrm{A} 1$ short $\square \mathrm{A} 1+\mathrm{OGly}+\mathrm{C}$
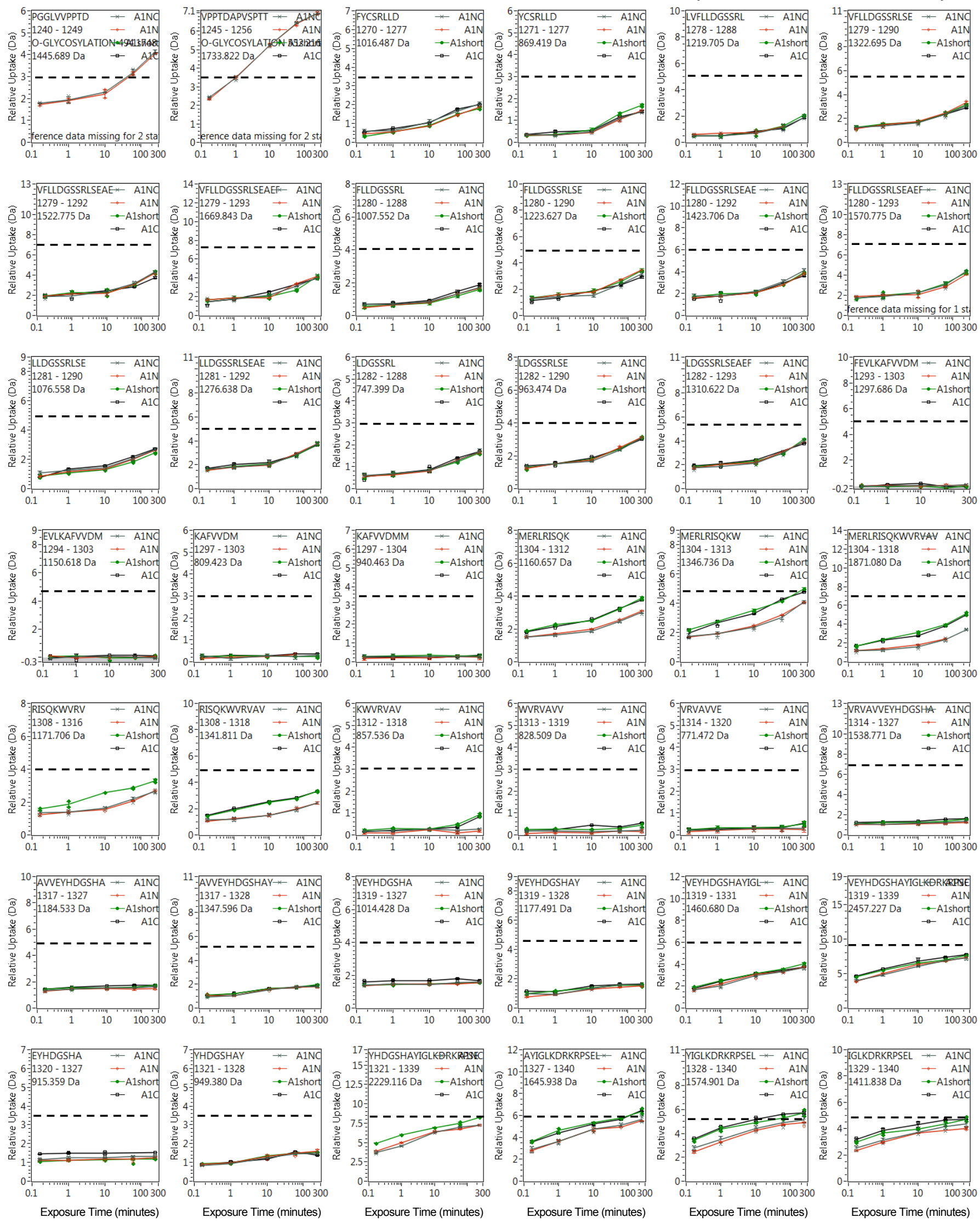

Figure 5 - Figure Supplement 3. Full HDX kinetics for peptides, one of three figures. 
bioRxiv preprint doi: https://doi.org/10.1101/2022.01.13.476208; this version posted January 13, 2022. The copyright holder for this preprint (which was not certified by peer review) is the author/funder, who has granted bioRxiv a license to display the preprint in perpetuity. It is made available under aCC-BY 4.0 International license.
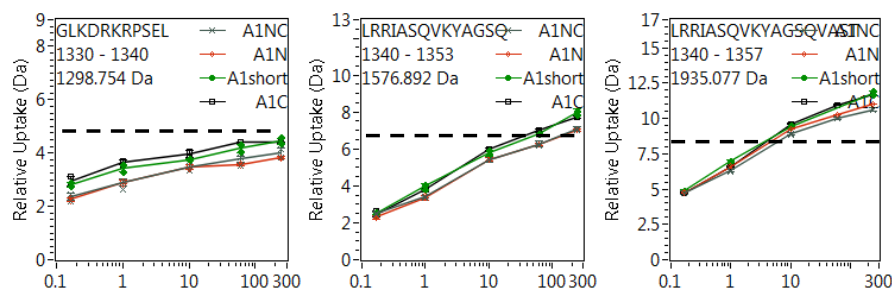

$X \mathrm{~A} 1+\mathrm{OGly}+\mathrm{N}+\mathrm{C}$

A1+OGly+N

A1 short $\mathrm{A} 1+\mathrm{OGly}+\mathrm{C}$
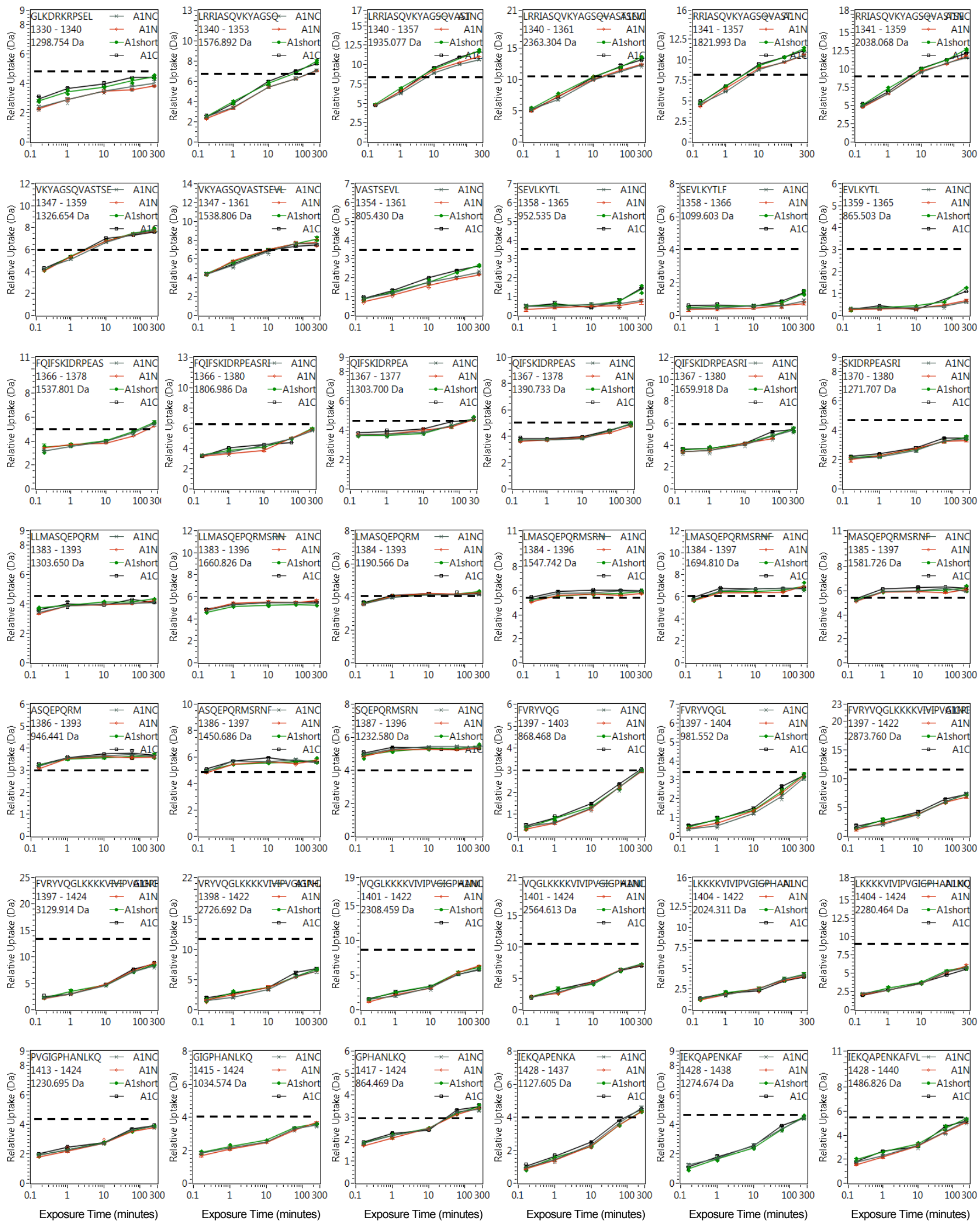

Figure 5 - Figure Supplement 4. Full HDX kinetics for peptides, two of three figures. 
bioRxiv preprint doi: https://doi.org/10.1101/2022.01.13.476208; this version posted January 13, 2022. The copyright holder for this preprint (which was not certified by peer review) is the author/funder, who has granted bioRxiv a license to display the preprint in perpetuity. It is made available under aCC-BY 4.0 International license.

\section{$X \mathrm{~A} 1+\mathrm{OGly}+\mathrm{N}+\mathrm{C} \bullet \mathrm{A} 1+\mathrm{OGly}+\mathrm{N} \odot \mathrm{A} 1$ short $\mathrm{DA} 1+\mathrm{OGly}+\mathrm{C}$}
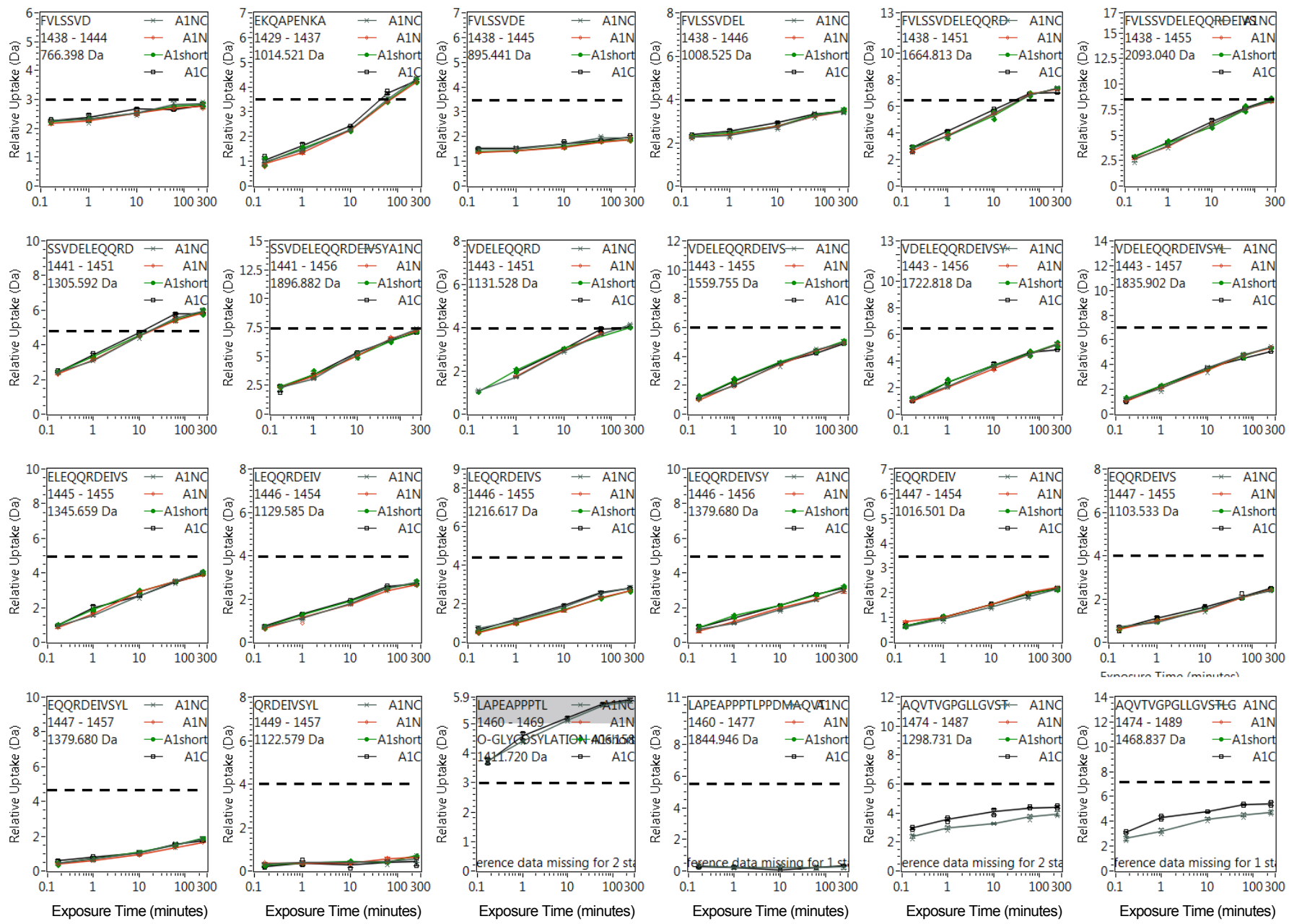

Figure 5 - Figure Supplement 5. Full HDX kinetics for peptides, three of three figures. 